\title{
Geology and Lithostratigraphy of the Ultramafic-Mafic Rocks and Associated Mineralizations, Wadi Khamal Area, West-Central Arabian Shield
}

\author{
H. M. Harbi \\ Department of Mineral Resources and Rocks, Faculty of Earth Sciences, \\ King Abdulaziz University, Jeddah, Saudi Arabia \\ harbihesham@hotmail.com
}

Received 25/6/2007

Accepted 5/2/2008

Abstract. Field, petrography and major elements geochemistry of the ultramafic -mafic rocks of Wadi Khamal area led to the recognition of the following rock groups, namely: 1) ophiolitic suite, melagabbronorite and cumulate gabbronorite to the south of Wadi Mahalah (southern ultramafic-mafic rocks) and 2) Wadi Khamal anorthositegabbro complex to the north.

The ophiolitic rocks in the southern area include serpentinites, peridotites and pyroxenites. The serpentinites contain large blocks of amphibolites, schists, gneisses, and metagabbros. These rocks were intruded by melagabbronorite and cumulate gabbronorite. On the AFM diagram, these rocks plot along the $\mathrm{MgO}-\mathrm{FeO}^{*}$ side in the tholeiitic field except those of the melagabbronorite which plot within the calcalkaline field.

The Wadi Khamal complex consists of four major units; marginal gabbro unit, anorthosite unit, central gabbroic unit and northern gabbronorite unit. The marginal gabbro unit and anorthosite unit have a calc alkaline differentiation trend while those of the central gabbro unit (olivine gabbro, melagabbronorite and $\mathrm{Fe}-\mathrm{Ti}$ oxides-apatite gabbronorite) and the northern gabbronorite show a distinct different trend parallel to the $\mathrm{FeO}^{*}-\mathrm{MgO}$ side line and belong to the tholeiitic differentiation trend. Based on major element geochemistry, the southern ultramafic - mafic rocks were derived from a more mafic liquid source rather different from magma source(s) which formed the Khamal anorthosite-gabbro complex.

The Fe-Ti oxides-apatite gabbronorite of the central unit of the Khamal complex hosts two main types of Fe-Ti oxide ores. 1) Massive bands of nelsonite ore consist mainly of magnetite, ilmenite, apa- 


\begin{abstract}
tite and minor amounts of silicates. It occurs in the form of bands and lenses of variable sizes intercalated with the magnetite-ilmeniteapatite gabbronorite, and 2) massive magnetite-ilmenite ore, which is less abundant compared to the nelsonite. The latter occurs as dyke-like bodies with nelsonite selvages within the anorthosite, or as bands or lenses enclosed within the nelsonite and close to the contact with the overlying anorthosite cap. The contact of magnetite-ilmenite ore with the nelsonite bands is gradational. The close spatial association and mineralogical similarities between the Fe-Ti oxides - apatite gabbronorite and the nelsonite, as well as the variable Fe-Ti oxides/apatite ratios suggest that the nelsonite was formed as accumulations due to in situ fractional crystallization of $\mathrm{Fe}, \mathrm{Ti}, \mathrm{P}$ and volatiles-rich gabbroic magma. The formation of the massive magnetite-ilmenite ore is attributed to high $f \mathrm{O}_{2}$ and mobility which promote later injection into the anorthosite host rocks.
\end{abstract}

\title{
Introduction
}

The Proterozoic layered ultramafic-mafic rocks of the Wadi Khamal area drew the attention of many researchers because they host numerous types of mineralization; e.g. $\mathrm{Cu}-\mathrm{Ni}(\mathrm{Pt})$ sulfides, Fe-Ti oxides and chromite. The area is located in the western central part of the Hijaz terrane, about $400 \mathrm{~km}$ north of Jeddah city. It is situated in the western part of Yanbu Al Bahr quadrangle (Sheet 24C, Pellaton, 1979) (Fig. 1).

The area was studied by many workers; Bache and Chevermont (1976), Pellaton (1979), Hashem (1981), Chevremont and Johan (1981), and Al Ghamdi (1994). The Wadi Khamal area has complex lithology and lithostratigraphy. The study area is dominated by a sequence of ultramafic-mafic rocks which belong to Wadi Khamal-Wadi Murattijah complex (Chevremont and Johan, 1981). These rocks intruded the metamorphic rocks of the Farri group and the post-Al Ays granitoid rocks (Pellaton, 1979). This rock sequence was intruded by younger granitic batholiths, and mafic dykes, and is locally overlain by Tertiary to Quaternary basalt flows, marine sediments and alluvial terraces.

The classification and origin of the ultramafic-mafic rocks in the Wadi Khamal area is a subject of controversy among the different workers. In the light of the present geological and geochemical studies a new lithostratigraphic sequence has been proposed. Moreover, the different types of mineralization associated with certain rock types within the rock sequence are also discussed. 


\section{Geologic Setting, Mapping and Petrography}

Integration of Landsat EMT+ and SPOT-5 data along with field verification were utilized in production of a 1:25,000 geological map for Wadi Khamal area. Band ratios technique was the main technique used for the lithologic discrimination (Drury, 1993) in which the DN value of one band is divided by the other DN value of the other band. The following band ratios 5/7:R; 7/1:G \& 5/1:B were generated throughout this study. SPOT-5 data was fused with the previously described band ratios image using IHS transformation method (Chavez and Bowell, 1988; Madani, 2003) to generate 1:25,000 image map (Fig.1) for Wadi Khamal area. The resulting fused image was integrated with the lineaments and major faults verified in the field to generate a geological map for the study area (Fig. 2).

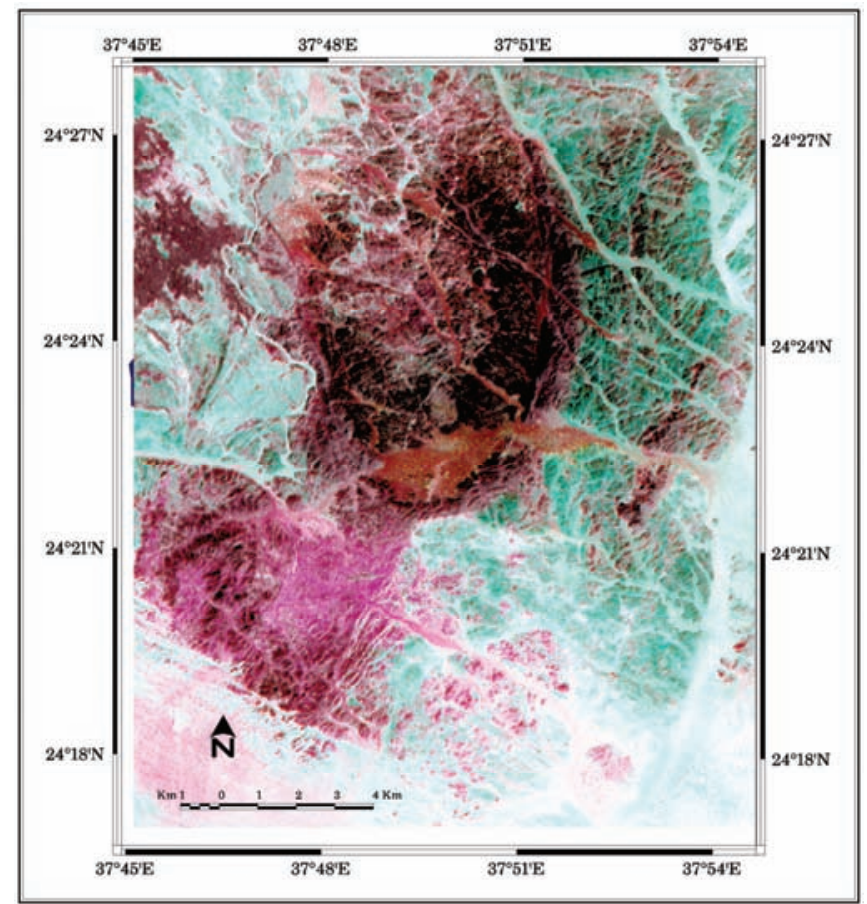

Fig. 1. Fused FCC band ratios image 5/7:R; 7/1:G \& 5/1:B for the study area.

In this study SPOT-5 data were used for lineaments analysis and extraction. The advantage of high spatial resolution of SPOT data makes it suitable for such analysis. Edge detection, threshold and linear feature 
extraction steps are the main processing steps carried throughout PCI LINE Package. Figure 2 shows the main trends of the automatically extracted lineaments over the study area. The main trends are NW -SE constituting the $33 \%$ of total lineaments number. NE-SW, E-W (ENE) and $\mathrm{N}-\mathrm{S}$ (NNW) are the main subordinate directions constitute $24 \%, 23 \%$ and $20 \%$ of total lineaments number (1179). Structural information extracted from the lineaments analysis together with the previous literature and field check were used to construct the geological map for the study area.

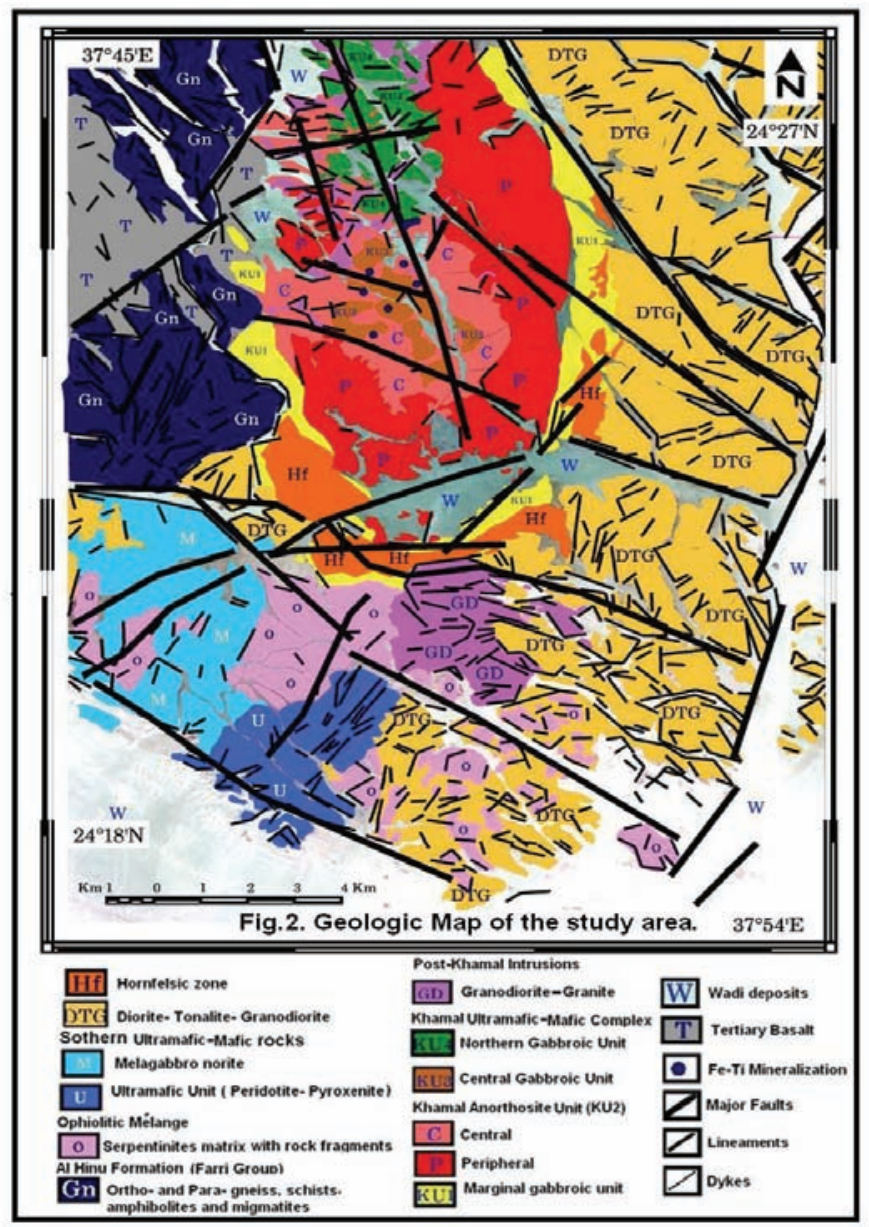

Fig. 2. Geological Map of the study area.

The most important structural elements recorded in the study area were faults which show the following main trends; NW -SE, NE-SW, E-W 
(ENE) and N-S (NNW). The ENE-WSW to E-W trend represents one of the main tectonic trends crossing the Neoproterozoic basement complex in the Arabian-Nubian Shield. ENE-WSW direction exhibits right lateral strike-slip sense which could be observed in the field and traced on the SPOT data.

The oldest rocks exposed in the Wadi Khamal area belong to the El Hinu Formation which represent an infrastructural unit. On the band ratios image (Fig. 1) this unit appears to have a pale green image signature. The rocks of the Al Hinu Formation are highly deformed and regionally metamorphosed up to amphibolite facies. They include para- and orthoamphibolite, quartzite, feldspathic schist and gnesisses (locally granitized and migmatized). The age of the Al Hinu formation rocks is uncertain, but Kemp et al., (1980) reported an age older than 780 Ma. Pellaton (1979) indicated that these rocks predate the emplacement of the Wadi Khamal complex and the southern ultramafic-mafic rocks, possibly belong to the Farri Group, or could represent an older basement. The other rocks in the Khamal area can be grouped into two distinct groups namely: an ophiolitic suite and gabbroic rocks exposed to the southwest of Wadi Mahalah; and the Wadi Khamal ultramafic - mafic complex (Fig. 2).

The ophiolitic mélange suite and the Wadi Khamal ultramafic - mafic complex, which are the target of the present study, are further intruded by younger granitoid rocks (Post-Khamal intrusions). The younger granitic rocks occupy the southeastern and northwestern parts of the mapped area (Fig. 2). They are of limited distribution and are found as dikes and small intrusive bodies into the ophiolitic rocks, the marginal gabbros and the anorthosites of the Khamal complex.

The correlation between the different classifications of the ultramafic-mafic rocks in the Wadi Khamal area is presented in Table 1 along with a new proposed classification tentatively arranged chronologically from oldest to youngest.

\section{The Ophiolitic Suite}

The rocks of the ophiolitic mélange suite were considered by some workers as a part of the Wadi Khamal-Al Murattijah complex (Chevermont and Johan, 1981 and Al Ghamdi, 1994) and as different rock units by others (e.g. Pellaton, 1979; Hashem, 1981 and Bache and Chever- 
mont, 1976). The ophiolitic mélange rocks which occur as isolated outcrops and as roof-pendants, are highly deformed and regionally metamorphosed up to the lower amphibolite facies. The ophiolitic rocks include the serpentinites, peridotites and pyroxenites.

Table 1. Summary of previous classifications of the ultramafic-mafic rocks in the Wadi Khamal area, with the proposed classification of the current study.

\begin{tabular}{|c|c|c|c|c|c|c|}
\hline \multirow[t]{2}{*}{\begin{tabular}{|c|} 
Bache and \\
Chevermont \\
$(1976)$ \\
\end{tabular}} & \multirow{2}{*}{$\begin{array}{c}\begin{array}{c}\text { Pellaton } \\
(\mathbf{1 9 7 9 )}\end{array} \\
\begin{array}{c}\text { Peralkaline } \\
\text { and alkali } \\
\text { granite }\end{array}\end{array}$} & \multicolumn{2}{|c|}{ Hashem (1981) } & \multicolumn{2}{|c|}{$\begin{array}{c}\text { Chevermont \& Johan } \\
\text { (1981) } \\
\text { Al Ghamdi (1994) } \\
\end{array}$} & Present Study \\
\hline & & \multicolumn{2}{|c|}{$\begin{array}{l}\text { Granite and } \\
\text { microgranite }\end{array}$} & 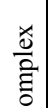 & $\begin{array}{l}\text { U6 Intermediate } \\
\text { intrusive unit }\end{array}$ & $\begin{array}{c}\text { Granite and micro- } \\
\text { granite }\end{array}$ \\
\hline \multirow{3}{*}{$\begin{array}{l}\text { North Basic } \\
\text { differenti- } \\
\text { ated com- } \\
\text { plex }\end{array}$} & \multirow{3}{*}{$\begin{array}{l}\text { Wadi } \\
\text { Khamal } \\
\text { complex }\end{array}$} & \multirow{3}{*}{\multicolumn{2}{|c|}{ Basic intrusion }} & 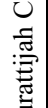 & $\begin{array}{l}\text { U5 Leucopyroxenite, } \\
\text { Melagabbro, Mela- } \\
\text { Leucotroctolite }\end{array}$ & \begin{tabular}{c|c} 
KU4 Northern \\
$\frac{\breve{\varrho}}{\mathrm{a}}$ & gabbronorite
\end{tabular} \\
\hline & & & & 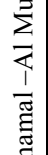 & \multirow{3}{*}{$\begin{array}{c}\text { U4 Mangerite- } \\
\text { Jotunite } \\
\text { Gabbronorite } \\
\text { Pigeonite gabbro } \\
\text { Anorthosite } \\
\text { Leuconorite }\end{array}$} & 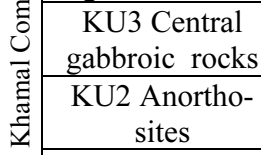 \\
\hline & & & & $\begin{array}{l}1 \\
: \vec{z} \\
i \\
3\end{array}$ & & $\begin{array}{c}\text { KU1 Marginal } \\
\text { gabbros }\end{array}$ \\
\hline $\begin{array}{c}\text { Diorite and } \\
\text { gabbro }\end{array}$ & Granite & \multirow{4}{*}{ 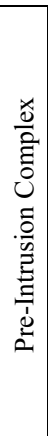 } & \multirow{3}{*}{$\begin{array}{l}\text { Diorite to- } \\
\text { nalite } \\
\text { Amphibo- } \\
\text { litized gab- } \\
\quad \text { bro }\end{array}$} & & & $\begin{array}{c}\text { Cumulate gabbro- } \\
\text { norite }\end{array}$ \\
\hline \multirow{2}{*}{$\begin{array}{l}\text { South ul- } \\
\text { tramafic- } \\
\text { mafic differ- } \\
\text { entiated } \\
\text { complex }\end{array}$} & \multirow{2}{*}{$\begin{array}{l}\text { Nabt layered } \\
\text { gabbro }\end{array}$} & & & & $\begin{array}{l}\text { U3 Amphibole gab- } \\
\text { bro unit }\end{array}$ & $\begin{array}{l}\text { Diorite, tonalite, } \\
\text { granodiorite, } \\
\text { melagabbronorite }\end{array}$ \\
\hline & & & & & $\begin{array}{l}\text { U2 Peridotite and } \\
\text { Pyroxenite }\end{array}$ & \multirow[b]{2}{*}{$\begin{array}{l}\text { Ophiolitic mélange } \\
\text { suite }\end{array}$} \\
\hline $\begin{array}{l}\text { South central } \\
\text { dunitic com- } \\
\text { plex }\end{array}$ & $\begin{array}{l}\text { Ultramafic } \\
\text { rocks }\end{array}$ & & $\begin{array}{l}\text { Ultramafic } \\
\text { complex }\end{array}$ & & $\begin{array}{c}\text { U1 Central dunite } \\
\text { unit }\end{array}$ & \\
\hline \multicolumn{7}{|c|}{ Farri Group (Al Hinu Formation) } \\
\hline
\end{tabular}

The serpentinites contain many ophiolitic and non ophiolitic rock blocks of variable sizes, few $\mathrm{cm}$ up to few meters diameter, and of diverse nature, igneous and metamorphic. On the band ratios image (Fig. 1), this unit shows pink image signature. The rock fragments are ophiolitic metagabbro, amphibolites, hornblende hornfels, diorite, pyroxenehornblende gneiss and tremolite schist (Fig. 3A).

The serpentinites contact with the melagabbronorite show development of a contact metamorphic aureole, tens of meters wide. Whole rock 
and mineral samples from the nearest ophiolitic rocks (Jabal Al Wask and Jabal Al Ess) yielded Sm-Nd isochron ages of $743 \pm 24$ and $782 \pm 38$ Ma (Claesson et al., 1984).

The essential rock type of the serpentinite is chrysotile-lizardite which consists of chrysotile, lizardite, magnetite and chromite, while close to melagabbronorite, metamorphic mineral assemblages of anthophyllite, tremolite, talc and magnesite are developed. The chrysotilelizardite serpentinite is blocky, sheared and fine grained with development of mesh and bastite textures. Chrysotile is the dominant serpentine polymorph, occurs as veinlets and microbands displaying a ribbon-like texture, or form the outer girdle of the mesh texture. Lizardite follows chrysotile in abundance and occurs as small platelets forming the core of some mesh texture, and as the main part of bastite. Tremolite occurs as long prismatic crystals and bundles ( 1 to $2 \mathrm{~mm}$ long) as well as fibro lamellar crystals. Talc occurs as fine-grained subhedral prismatic and flaky forms.

Peridotites are slightly serpentinized and locally contain patches of gossan with copper staining. These rocks are intruded by melagabbronorite dykes which are slightly tectonized.

Pyroxenites are observed as roof-pendants on the cumulate gabbronorite (Fig. 3B). Along the eastern margin, the layered peridotite and pyroxenite are intruded by dyke-like granite bodies parallel to the layering (Fig. 3C).

Peridotites include weherlite and lherzolite, both are massive. Locally, they occur as thick bands alternating with pyroxenites. Wehrlite consists of olivine, clinopyroxene, and magnetite. Chlorite and serpentine minerals (chrysotile, lizardite, serpophite and brown iddingsite) represent secondary minerals almost entirely after olivine. Lherzolite is less affected by serpentinization and consists of olivine 50-60\%, clinopyroxene, $25-35 \%$, and orthopyroxene, $15-20 \%$.

Pyroxenite is the most abundant rock type of the southern ultramafic rocks. The rock is melanocratic, medium- to coarse-grained and consists almost entirely of clino- and orthopyroxene, over $95 \%$ of the rock mode. 


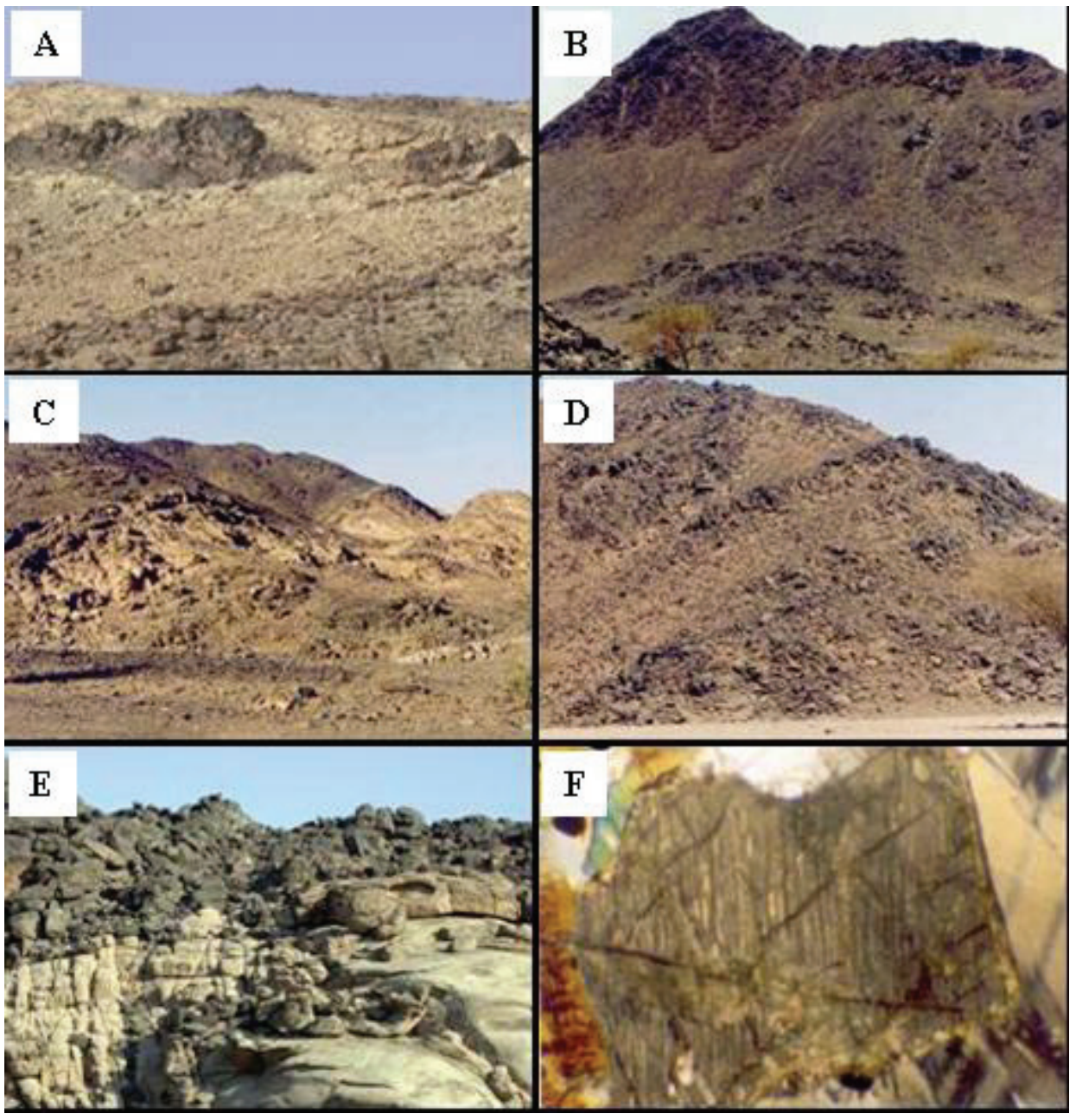

Fig. 3. A. Metagabbro fragments in serpeninites.

B. A pyroxenite roof-pendant carried by cumulate gabbronorite.

C. Layered pyroxenite and peridotite intruded by younger granite .

D. Layering in marginal gabbro at the entrance of Wadi Al Khishirma. Looking east.

E. A roof-pendant from the marginal gabbro carried by the younger granite. Southern margin of the marginal gabbro. Looking north.

F. Exsolution intergrowths of clinopyroxene as very thin lamina (hair-like) in orthopyroxene. C.N., 110x. 
The clinopyroxene / orthopyroxene ratio shows great variation, and gradation may exist from clinopyroxenite to orthopyroxenite. Primary accessory phases include olivine, plagioclase, magnetite, ilmenite, and sulfides.

\section{Diorite-Tonalite-Granodiorite Complex}

The rocks of the ophiolitic mélange suite were intruded by granitoid rocks of the diorite-tonalite-granodiorite complex which show green image signature with reddish spots (Fig. 1). The rocks mainly exposed on the eastern and southern parts of the area, were intruded by Wadi Khamal complex. Hornfelsic zone up to $1 \mathrm{~m}$ wide was recognized in the diorite rocks, very close to the contact with the marginal gabbro of Wadi Khamal complex (Fig. 2). These rocks intrude and carry roof-pendants from the ophiolitic rocks. Similar tonalites from Jabal Salajah north of the study area, yielded an age of $\approx 725 \mathrm{Ma}$ by $\mathrm{Rb}-\mathrm{Sr}$ method (Kemp et al., 1980).

\section{Melgabbronorite}

The melagabbronorite is mainly exposed in the southwestern part of the area and is characterized by the presence of numerous roof-pendants of the ophiolitic serpentinities (Fig. 2). The rocks are fine grained (0.5$2 \mathrm{~mm}$ ), melanocratic (modal pyroxene range from $75-85 \%$ of the rock) with blackish- to grayish green color. It consists essentially of clino- and orthopyroxene, andesine and olivine in decreasing order of abundance. Brownish to pale green amphiboles are relatively abundant in some samples, formed on the expense of pyroxene. Accessories of opaques and apatite are of scarce abundance, most occur either as inclusions in pyroxene or in the interstices between the silicate minerals. The melagabbronorite was considered to be older than Al Ays Group which has an age of $684 \mathrm{Ma}$ (Pellaton, 1979). On the band ratios image (Fig. 1) these units show red image signature.

\section{Cumulate Gabbronorite}

The cumulate gabbronorite occurs in the southwestern part of the area intruded the ophiolitic ultramafic rocks and has not been described before. It is of limited distribution and unmappable and occupies the floor of the wadies in association with the southern ultramafic rocks. The cumulate gabbronorite is geochemically different from the melagabbro- 
norite (see geochemistry section). The rock exhibits cumulate texture and is both massive and foliated, melanocratic with dark greenish color. The cumulate gabbronorite consists of plagioclase of andesine composition ( $\mathrm{An}_{45-52}$ and $\mathrm{An}_{48}$ on average), clinopyroxene, orthopyroxene, Fe-Ti oxides and apatite in relative decreasing abundance. Green hornblende locally forms secondary reaction rims around the ortho- and clinopyroxene. Plagioclase is the most abundant phase, $50-60 \%$.

\section{Khamal Anorthosite-Gabbro Complex (KAGC)}

The ultramafic-mafic rocks of the Khamal anorthosite-gabbro complex (KAGC) are exposed mainly north of Wadi Al Mahallah forming an elliptical body $5 \times 12 \mathrm{~km}$ trending $\mathrm{N} 15^{\circ} \mathrm{W}$. They are considered to represent a separate intrusion, referred to as Khamal anorthosite-gabbro complex. The complex constitutes gabbros, and anorthosites as well as numerous occurrences of Fe-Ti mineralization. The marginal gabbronorite unit represents the chilled margin of the intrusion where a hornfelsic zone occurs in the older dioritic rocks of the diorite-tonalite-granodiorite complex. The rocks of the hornfelsic zone were described as jotunite and mangerite by Pellaton (1979) and were considered as a part of the intrusion. On the basis of field and petrographic studies, the complex is divided into four units namely; 1) KU1 Marginal gabbro unit, 2) KU2 Anorthosites, 3) KU3 Central gabbros, and 4) KU4 Northern gabbronorite.

\section{Marginal Gabbro Unit (KU1)}

The marginal gabbro unit (KU1), forms a horse-shoe like body with variable lithological composition and width $(\approx 1 \mathrm{~km}$ wide), and shows a pronounced layering (Fig. 3D). On the band ratios image (Fig. 1), it is dark red. South of Wadi Al Mahallah, the marginal gabbro is intruded by the younger granite which contains roof-pendants of it (Fig. 3E). The contact is characterized by a hornfels zone of tens of meters in width where hornblende is recrystallized to granular pyroxene. Three rock types are recognized forming the marginal gabbro: a) coarse-grained norite, b) medium-grained gabbronorite, and c) medium-grained gabbro. The contacts between these rock types are gradational and oftenly difficult to be delineated in the field.

a- The coarse-grained norite is melanocratic and consists essentially of orthopyroxene and plagioclase. The later shows variation in abundance ranges from $35 \%$ to $50 \%\left(\mathrm{An}_{48-58}\right.$; average of $\left.\mathrm{An}_{54}\right)$. Primary ac- 
cessory minerals include Fe-Ti oxides, clinopyroxene, quartz, biotite and apatite. Most orthopyroxene crystals contain exsolution intergrowths of clinopyroxene as very thin to hair-like crystals along the cleavage planes of orthopyroxene (Fig. 3F). Abundant reddish brown to brown and black inclusions and acicular rutile are very abundant in orthopyroxene, developing schiller structure. Opaque minerals include magnetite, hematite, ilmenite and hemoilmenite.

b- The medium-grained gabbronorite constitutes the major part of the marginal gabbro unit (KU1). It is melanocratic and consists of orthopyroxene, clinopyroxene and plagioclase of andesine composition ( $\mathrm{An}_{44-}$ 52; average $\mathrm{An}_{48}$ ). The plagioclase constitutes about $40 \%$ to $60 \%$. Minor primary phases include, in relative decreasing abundances, olivine, hornblende, biotite, ilmenite and apatite. The gabbronorite shows wide variation in the ortho-pyroxene/clinopyroxene ratio. Orthopyroxene crystals contain abundant exsolution lamellae of clinopyroxene, and poikilitic inclusions of Fe-Ti oxides.

c- The medium-grained gabbro, locally grades to olivine gabbro, represents a minor part of the marginal gabbro unit. The rock is mediumgrained, melanocratic and consists of plagioclase, clinopyroxene, and minor quartz, olivine, opaques and orthopyroxene. Plagioclase is the most abundant from $50 \%$ to $60 \%$ of the rock. The plagioclase displays a wide compositional range $\left(\mathrm{An}_{38-47}\right)$ with an average of $\mathrm{An}_{44}$.

\section{Khamal Anorthosite Unit (KU2)}

Based on the band ratios image (Fig. 1) two types of Khamal anorthosites were distinguished: a) the central and b) the peripheral types. These units show pale red and brick red image signatures respectively. The Khamal anorthosite unit (KU2), which was intermittently quarried, is a massif-type andesine anorthosite, according to the definition of Emslie and Hegner (1993) and Ashwal (1993). The anorthosite which forms the core of the complex and constitutes the major part of the KAGC was intruded by the olivine gabbro, melagabbronorite and oxides-apatitebearing gabbronorite and (KU3) and the northern gabbronorite (KU4). Large xenoliths and rafts of the anorthosite are encountered in the KU3 and KU4 units. The anorthosite also occurs as roof-pendents in the oxides-apatite-bearing gabbronorite (KU2). The contact between the anorthosite and the marginal gabbro (KU1) is locally gradational, but in other instances sharp contacts are also recorded. The anorthosites are intruded 
by dike-like granitic bodies (Fig. 4A). The relationship between these dike-like granitic rocks and the granitic bodies intruded into the southern ultramafic-mafic and the marginal gabbro is difficult to assess in the absence of chemistry and age dating.

These anorthosites are leucocratic and show great color variation (grey, deep bluish grey, dark violet-grey to blackish violet) and grain size $(0.2 \mathrm{~mm}$ to $6 \mathrm{~mm})$. The coarse-grained variety displays typical cumulate texture (Fig. 4B). The anorthosite consists of plagioclase of andesine composition $\left(\mathrm{An}_{45-54}\right)$ and minor clinopyroxene. Accessory minerals include apatite, Fe-Ti oxides and rutile. Secondary minerals include chlorite, amphibole, epidote, quartz and sericite. Clinopyroxene, which is the main mineral, is fine- to medium-grained, anhedral, sometimes with fluidal-like form occupying the interstices between the coarse feldspar crystals (Fig. 4C). Some crystals are partially altered to green amphibole (actinolite-uralite mixture). Presence of chlorite associated with quartz and epidote in some feldspar grains indicates that this assemblage is the product of feldspar alteration.

\section{Central gabbroic unit (KU3)}

These rocks occupy the central part of the KAGC and are younger than the anorthosites, where rafts and xenoliths of different sizes as well as roof pendants of anorthosite are enclosed in the melagabbronorite (Fig. 4D) all suggesting the intrusive nature of this unit. Based on field and petrographic study, the central gabbroic rocks can be differentiated into three rock types differing in appearance, layering and associated mineralizations, namely: a) olivine gabbro, b) melagabbronorite and c) Fe-Ti oxides-apatite gabbronorite.

a) The olivine gabbro is the least abundant rock type in the central gabbroic unit and constitutes most of the southern part of it. Layering is parallel to overlying melagabbronorite. On the band ratios image (Fig. 1), this unit shows dark red image signature. The olivine gabbro consists of olivine, clinopyroxene (diopside to diopsidic augite), orthopyroxene, plagioclase, minor hornblende, oxides and accessory apatite. Olivine is the requently abundant and some crystals show subsolidus reaction with the development of clinopyroxene corona texture. Few crystals of clinopyroxene are altered to brownish hornblende. Most of the orthopyroxene (bronzite) contain exsolution intergrowths of clinopyroxene. Plagioclase is medium to coarse grained, prismatic to lath-like shape with an average 
composition (An 70-80), and as fine granular crystals possibly recrystallized under equilibrium conditions. Ilmenite and magnetite are abundant.

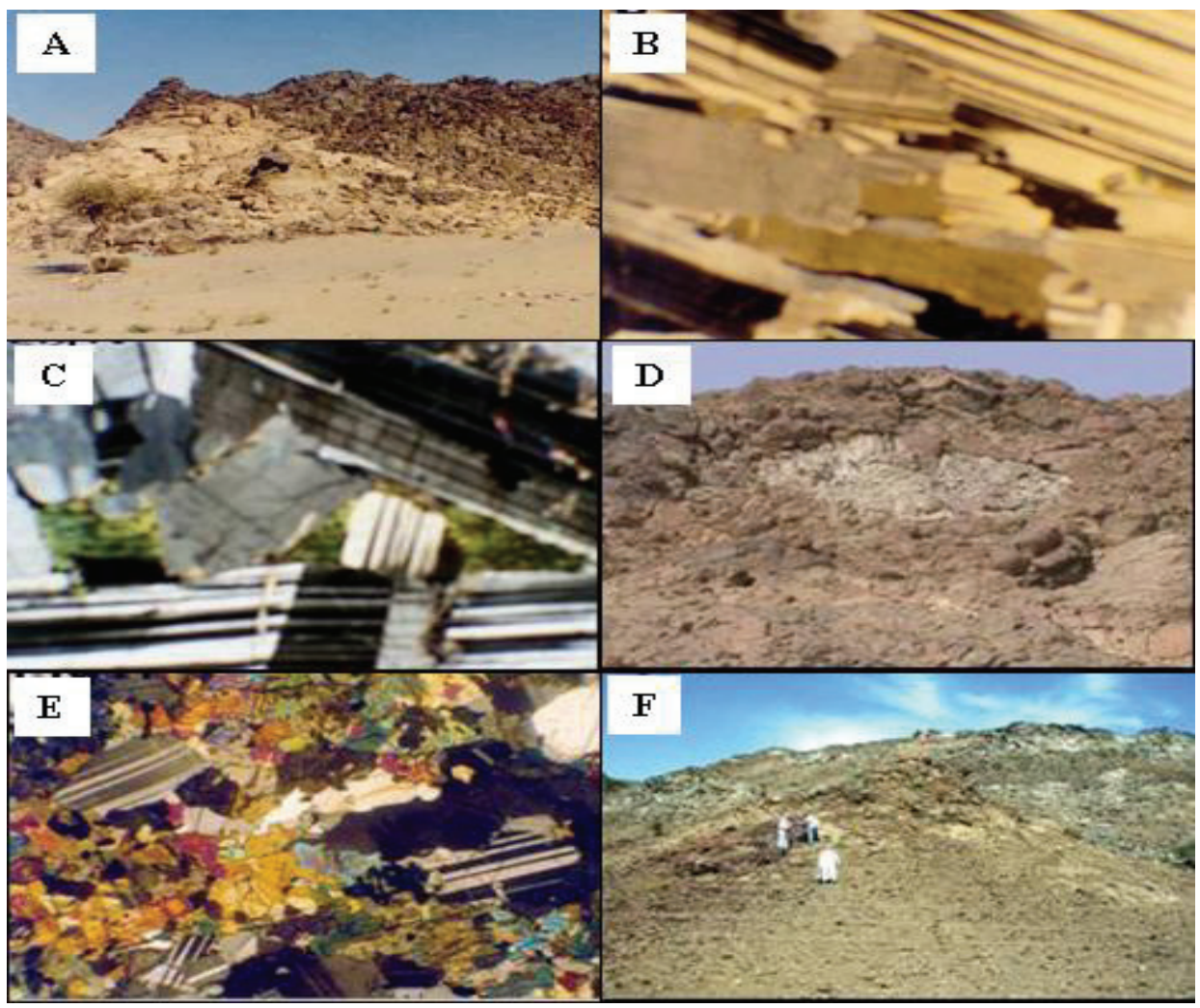

Fig. 4. A. A younger granite dyke intruding the anorthosite.

B. Anorthosite showing well developed cumulate texture. C.N., 110x.

C. Clinopyroxene as intercumulus phase between large cumulate plagioclase feldspar. The clinopyroxene occupies the interstices between the plagioclase crystals. C.N., 30x.

D. Melagabbronorite enclosing an anorthosite block.

E. Cluster aggregates of fine-grained clino- and orthopyroxene forming subparallel bands imparting to the rock cumulate texture in the cumulate melagabbronorite. C.N., 30x.

F. Gossaneous materials in melagabbronorite.

b) The melagabbronorite is characterized by the presence of cumulus pyroxene layers and intercumulus plagioclase, disseminated sulfides, and the presence of numerous gossaneous bodies. On the band ratios image (Fig. 1), this unit appears with violet image signature. It is melanocratic with $>70 \%$ mafic minerals. In thin sections, it consists of clino- and orthopyroxene, and plagioclase. Accessory minerals are magnetite, ilmen- 
ite, chalcopyrite, pyrrhotite, and pyrite with rare apatite. Clino- and orthopyroxene form subparallel elongated patches and bands of cluster aggregates imparting to the rock the cumulate texture (Fig. 4E). The plagioclase feldspar is less abundant, 30-45\%. Sulfide minerals are common and include chalcopyrite, pyrrhotite and less common pyrite. Ilmenite and magnetite are also abundant.

The melagabbronorite is associated with a gossan of limited extension, few square meters up to tens of square meters, occurs in the central part of Wadi Khamal area (Fig. 4F). The gossans occur in veinlets and massive bodies (Fig. 5A) and composed mainly of iron oxides. Opaques mineral sulfides and oxides are commonly disseminated between and enclosed by the pyroxenes and rarely with plagioclase. The sulfides mainly pyrrhotite is commonly altered to marcasite (Fig. 5B) with minor amounts of pyrite and chalcopyrite. The oxides are represented by homogenous ilmenite and magnetite (Fig. 5C).

Representative samples from the melagabbronorite and associated gossans were analyzed for their $\mathrm{Au}, \mathrm{Pt}, \mathrm{Pd}, \mathrm{Cu}$ and $\mathrm{Ni}$ contents at ACME labs; Canada. The results are shown in Table 2. The Au, Pt, Pd and Ni values of the melagabbronorite are below the average of the mafic rocks while $\mathrm{Cu}$ values are slightly higher. The gossans are slightly enriched in $\mathrm{Au}, \mathrm{Pt}, \mathrm{Pd}$, when compared with melagabbronorite, but the reported values are not encouraging. A sample from the same gossan exposures gave $7.2 \mathrm{~g} / \mathrm{t} \mathrm{Pt}, 0.82 \mathrm{~g} / \mathrm{t} \mathrm{Pd}$ and $6.2 \mathrm{~g} / \mathrm{t} \mathrm{Au}$, and sulfide mineralization which was intersected by drill holes gave $0.4 \mathrm{~g} / \mathrm{t} \mathrm{Pt}$ and $0.27 \mathrm{~g} / \mathrm{t} \mathrm{Pd}, 0.71 \% \mathrm{Ni}$ (Collenette and Grainger, 1994). It is recommended to drill more holes along the strike of the melagabbronorite layer which is generally dipping to the north underneath the Fe-Ti oxides-apatite gabbronorite.

Table 2. Au, Pt, Pd Cu and Ni contents (ppm) of melagabbronorite and associated gossans; Khamal central gabbroic unit .

\begin{tabular}{|c|c|c|c|c|c|c|}
\hline \multirow{6}{*}{ 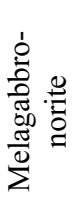 } & Sample \# & $\mathbf{A u}$ & $\mathbf{P t}$ & Pd & $\mathbf{C u}$ & $\mathbf{N i}$ \\
\hline & 1 & - & - & - & 91 & 28 \\
\hline & 2 & - & - & - & 93 & 19 \\
\hline & 3 & - & - & 0.01 & 95 & 22 \\
\hline & $89 \mathrm{~B}$ & - & - & 0.01 & 80 & 19 \\
\hline & 258 & - & - & 0.01 & 81 & 37 \\
\hline \multirow{4}{*}{ 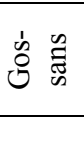 } & 0 & 0.04 & - & 0.01 & na & $\mathrm{Na}$ \\
\hline & 8 & 0.02 & - & 0.03 & na & $\mathrm{Na}$ \\
\hline & 90 & 0.02 & 0.01 & 0.02 & na & $\mathrm{Na}$ \\
\hline & Mafic Rocks* & 0.0032 & 0.03 & 0.021 & 72 & 130 \\
\hline
\end{tabular}

* Average of mafic rocks after Rose et al. (1979)., $-=<0.1$, na $=$ not analyzed 


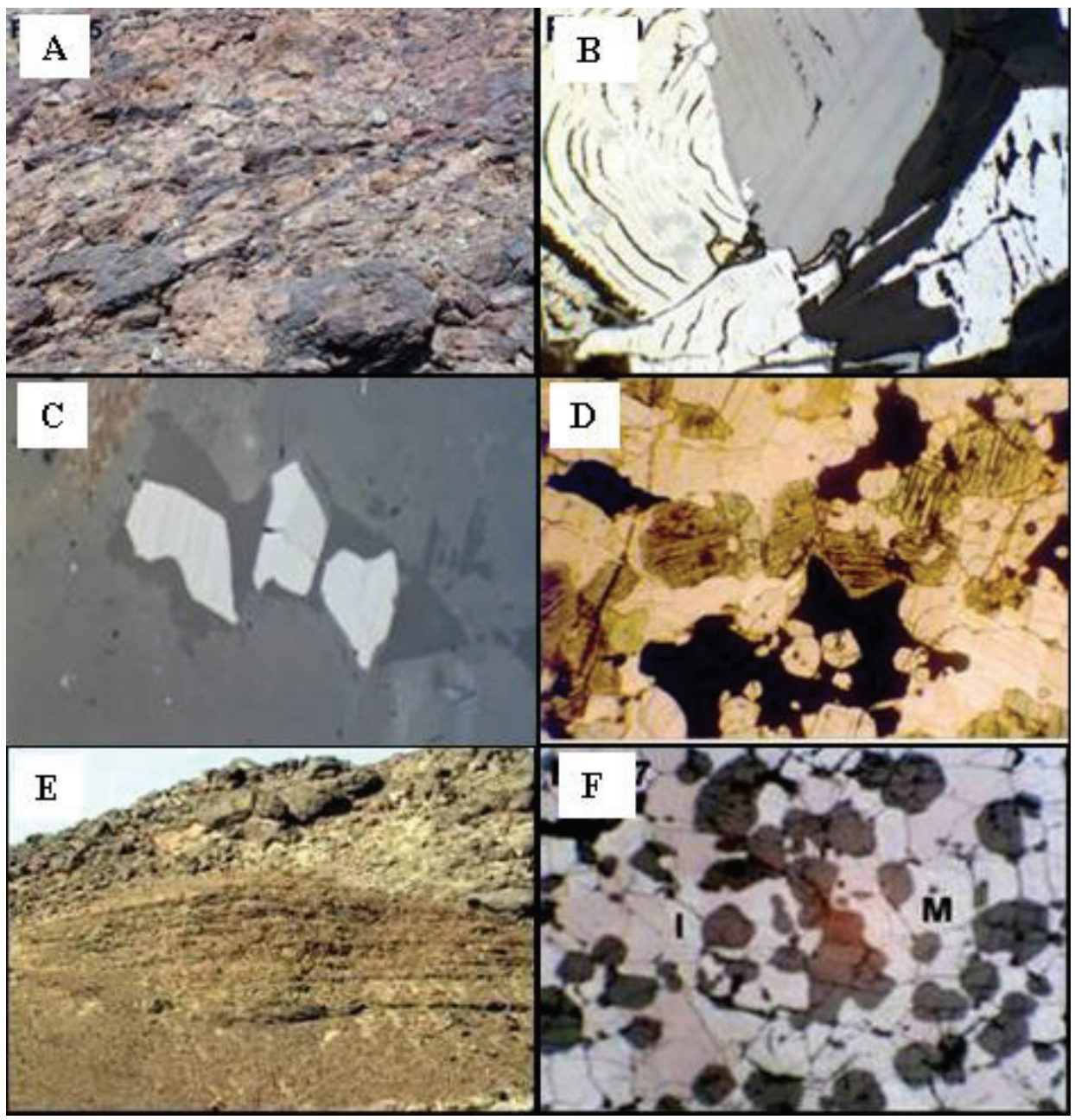

Fig. 5. A. Veinlets and massive bodies of iron oxides in melagabbronorite associated gossans.

B. Magnetite with ilmenite trellis intergrowths associated with pyrrhotite altered to marcasite. P.T.S., P.P.L., 550x.

C. Discrete magnetite with ilmenite intergrowths enclosed in pyroxenes. P.T.S., P.P.L., 550x.

D. A close association of cluster aggregates of apatite and ilmenite in the $\mathrm{Fe}-\mathrm{Ti}$ oxide-apatite gabbronorite. P.P.L., 30x.

E. A layered sequence of massive and disseminated nelsonite ores at sharp contact with anorthosite.

F. Massive nelsonite ore consisting of rounded and subhedral apatite (dark grey) setin a ground mass of magnetite (M) and ilmenite (I). P.S., P.P.L., 30x.

c) The Fe-Ti oxides-apatite gabbronorite occurs in the central part of the KAGC and is noticeably enriched in opaques and apatite. The apatite 
constitutes up to $5 \%$. This rock consists of clinopyroxene and plagioclase with minor orthopyroxene, magnetite and ilmenite and apatite. Plagioclase is the most abundant, $40-50 \%$. It is a soda labradorite $\left(\mathrm{An}_{45-58}\right.$, average $\mathrm{An}_{52}$ ). Clinopyroxene is the second most abundant. Chadacrysts of apatite and ilmenite are frequent in clinopyroxene. Apatite occurs as large subhedral to euhedral crystals, $0.2 \mathrm{~mm}$ up to $2 \mathrm{~mm}$, sporadically scattered and form cluster aggregates with ilmenite (Fig. 5D).

A recent study by Harbi et al. (2006), led to the discovery of a nelsonite-type deposits and described two main types of the Fe-Ti oxide mineralizations associated with the Fe-Ti oxides - apatite gabbronorite of the central gabbroic unit (KU3): a) massive nelsonite bands consist of magnetite-ilmenite and apatite in different proportions with minor interstitial silicates and b) massive magnetite-ilmenite ore which occurs either as bands intercalated with nelsonite or as dike-like bodies hosted by the anorthosite in contact with $\mathrm{Fe}-\mathrm{Ti}$ oxides - apatite gabbronorite.

\section{a) Massive magnetite-ilmenite-apatite mineralization (Nelsonite)}

This type of mineralization occurs in massive layers or bands, tens of cms up to $\approx 20 \mathrm{~m}$ in thickness and extends for tens of meters up to $100 \mathrm{~s}$ of meters along strike (Fig. 5E). The massive ore is composed essentially of magnetite, ilmenite and variable apatite content $(15-40 \%, X=24.69 \%)$ (Fig. 5F). Other minerals identified include plagioclase, pyroxene, green spinel, and sulfides (mainly pyrite, pyrrhotite and chalcopyrite) which constitute less than $10 \%$ of the ore mode. The contact between the massive ore and the mineralized gabbronorite is either sharp or gradational (Figs. 6A and 6B). Close to the contact with the Fe-Ti oxides-apatite gabbronorite, the banded massive ore is characterized by ovoid to lensoid inclusions (up to $10 \mathrm{~cm}$ in diameter) (Figs. 6C and 6D). These inclusions are mineralogically similar to the gabbronorite and contain disseminated Fe-Ti oxides $(\approx 10 \%)$, but they are fine-grained compared to those of the gabbronorite. Also, the apatite crystals in these inclusions are very finegrained $(0.12 \mathrm{~mm})$ compared to those present in the massive ore (few $\mathrm{mms}$ in diameter).

\section{b) Massive magnetite-ilmenite}

This type is found as dyke-like bodies, few meters thick and tens of meters long, intruded the anorthosites and is usually found in close proximity to the nelsonite (Fig. 6E). The margins of these dyke-like bodies are charac- terized by the presence of nelsonite envelopes of variable 
thickness. Also, the massive magnetite-ilmenite ore occurs as bands locally intercalated with nelsonite, where the contact with the later is gradational.

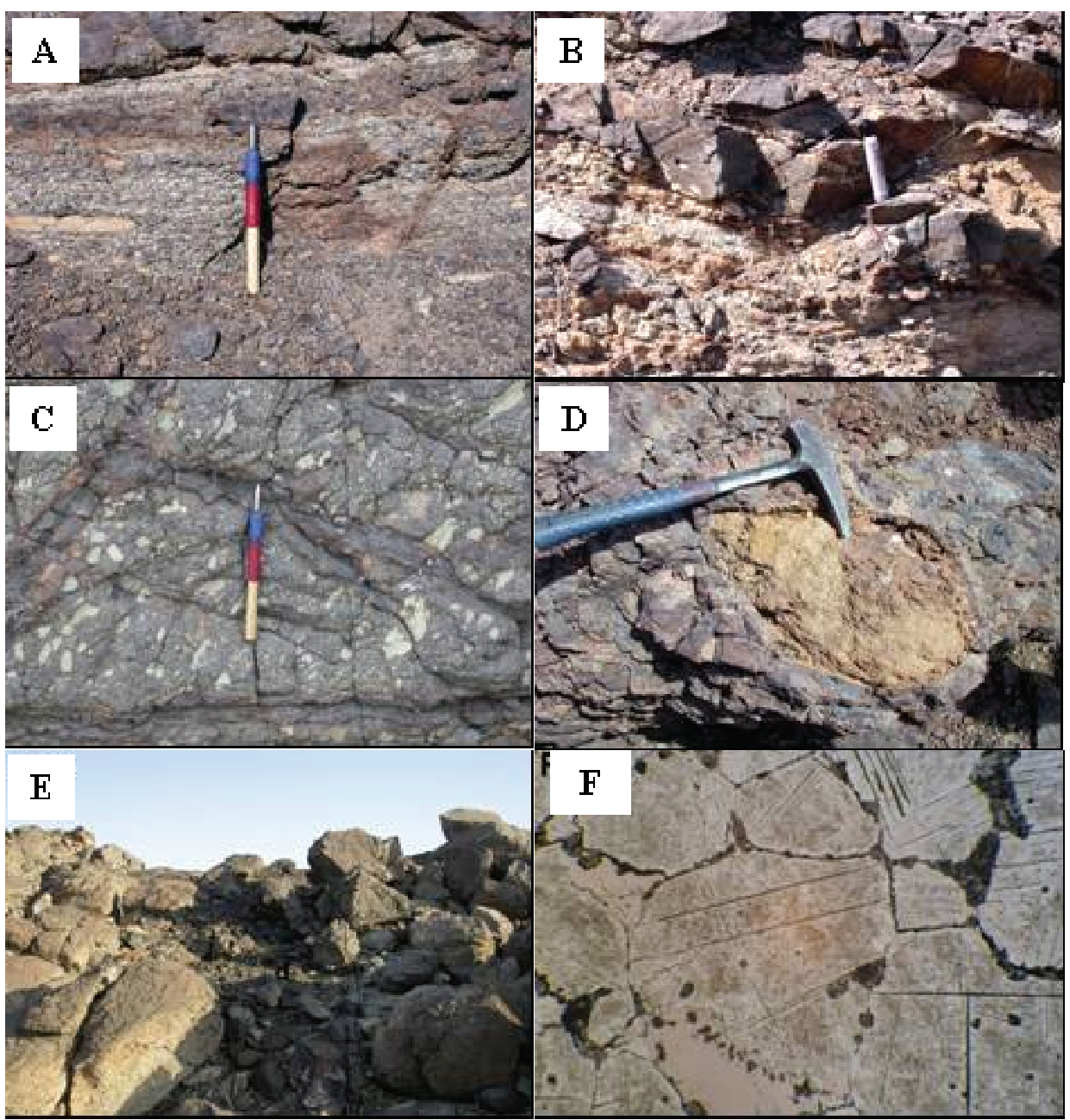

Fig. 6. A. Massive nelsonite ore interlayered with disseminated ore. The upper and lower contacts seem to be gradational.

B. Sharp contacts between bands of massive nelsonite ore interlayered with disseminated ore in gabbronorite.

C. Small ovoid inclusions in the massive nelsonite ore.

D. A large ovoid inclusion of fine-grained gabbronorite incorporated within the massive nelsonite ore.

E. Massive magnetite -ilmenite dyke (d) in anorthite.

F. Polygonal magnetite aggregates with interstitial ilmenite granules. Notice green spinel and silicates along grain boundaries. P.S., P.P.L., 30x. 
This type of ore consists essentially of magnetite (60\%) and ilmenite $(\approx 35 \%)$. Other minerals identified $(<5 \%)$ include green spinel and a silicate mineral (chlorite ?) and occur as fine grains along the contact as well as the triple junction points between ilmenite and magnetite crystals (Fig. 6F). The close spatial association, mineralogical similarities between the gabbronorite and the nelsonite, and the variable Fe-Ti oxides/apatite ratios suggest that the nelsonite was formed as accumulations by in situ fractional crystallization of $\mathrm{Fe}, \mathrm{Ti}, \mathrm{P}$ and volatiles-rich gabbroic magma. The formation of the massive magnetite-ilmenite ore is attributed to high $f \mathrm{O}_{2}$ and later mobility and injection into the anorthosite host rocks.

\section{Northern Gabbronorite Unit (KU4)}

The northern gabbronorite unit (KU4) occupies the northern part of the KAGC. Unlike the central gabbroic unit (KU3), the rocks of the northern gabbronorite are devoid of Fe-Ti mineralization. However, it consists of feldspar, clinopyroxene, orthopyroxene and opaque oxides with minor olivine. The plagioclase has an andesine composition $\left(\mathrm{An}_{40-46}\right)$. On the band ratios image (Fig. 1) this unit shows dark red image signature.

\section{Major Oxides Geochemistry}

This section deals with the major elements geochemical characteristics of the ultramafic-mafic rocks of the Wadi Khamal and and Nabt ultramafic-mafic rocks in the south and south west of the study area (17 and 74 samples, respectively). The later includes the ophiolitic rock suite (serpentinites, pyroxenites and peridotites), the melagabbronorite and the cumulate gabbronorite. The diversity of these two complexes as indicated by the field relationships and petrographic studies is also confirmed using the major element characteristics of the different rock types. Major elements were determined by inductively coupled plasma-mass spectrometry (ICP-MS) after fusion of $0.2 \mathrm{gm}$ of the powdered sample by $\mathrm{LiBO}_{2}$, at the ACME analytical laboratories, Canada. Total $\mathrm{C}$ and $\mathrm{S}$ were determined by Leco, and loss on ignition (LOI.) is determined by heating a known weight of sample to $1000^{\circ} \mathrm{C}$ for one hour. The total carbon is recalculated as $\mathrm{CO}_{2}$. 


\section{Major Elements Characteristics of Southern Ultramafic-Mafic Rocks}

The major element contents of the southern ultramafic-mafic rocks show wide variations (Table 3 ). The melagabbronorite unit shows an overall higher $\mathrm{SiO}_{2}, \mathrm{TiO}_{2}, \mathrm{Al}_{2} \mathrm{O}_{3} \mathrm{Na}_{2} \mathrm{O}$, and $\mathrm{K}_{2} \mathrm{O}$, and lower $\mathrm{MgO}$ and $\mathrm{Fe}_{2} \mathrm{O}_{3}$ than the other rocks. These chemical features are best shown in the variation diagrams (Fig. 8), where $\mathrm{MgO}$ is used as an index of fractionation. Although, field relationships of the melagabbronorite rocks to the ophiolitic rocks and the cumulate gabbronorite are obscured and difficult to be verified in the field, yet major element variations reveal that these rocks plot in three distinct compositional fields and trends (Fig. 8).

Peridotites (lherzolite and weherlite) display the highest $\mathrm{MgO}$ content, from $32 \mathrm{wt} \%$ in lherzolite to $23 \mathrm{wt} \%$ in weherlite (Table 3 and Fig. 8). These samples have rather uniform major element composition, except one weherlite sample (highly serpentinized) has relatively high $\mathrm{SiO}_{2}, \mathrm{CaO}$ and lower $\mathrm{Fe}_{2} \mathrm{O}_{3}$ contents. $\mathrm{Al}_{2} \mathrm{O}_{3}, \mathrm{CaO}, \mathrm{Na}_{2} \mathrm{O}, \mathrm{K}_{2} \mathrm{O}$, and $\mathrm{TiO}_{2}$ contents of both rock types are generally low. The cumulate nature of the ultramafic rocks is evident on the $\mathrm{MgO}-\mathrm{CaO}-\mathrm{Al}_{2} \mathrm{O}_{3}$ ternary diagram (Fig. 9), where they approach and overlap the field of metamorphic peridotite and ultramafic cumulate. The pyroxenite falls mainly in the field of ultramafic cumulate. Al Gamdi (1994) analyzed the pyroxenites and the harzburgite for the PGEs in addition to $\mathrm{Ni}$ and $\mathrm{Cu}$ and found that the pyroxenite are characterized by higher $\mathrm{Ni} / \mathrm{Cu}$ ratios and lower $\mathrm{Pd} / \mathrm{Ir}$ ratios which indicate their ophiolitic affinity.

Table 3. Major oxides of the southern ultramafic-mafic rocks.

\begin{tabular}{|c|ccccccccc|cccc|}
\hline \multicolumn{1}{|c|}{ Ultramafic rocks (Peridotite) } & \multicolumn{3}{c|}{ Pyroxenite } & \multicolumn{3}{c|}{ Cumulate gabbronorite } \\
\hline Sample & 131 & 132 & 133 & 137 & 138 & 134 & 135 & 136 & 139 & 146 & 147 & 148 \\
\hline $\mathrm{SiO} 2$ & 36.96 & 36.71 & 42.18 & 37.78 & 36.08 & 50.45 & 50.89 & 52.43 & 49.47 & 49.76 & 51.37 & 50.24 \\
$\mathrm{TiO} 2$ & 0.07 & 0.07 & 0.29 & 0.16 & 0.10 & 0.44 & 0.32 & 0.31 & 0.49 & 0.66 & 0.29 & 0.37 \\
$\mathrm{~A} 2 \mathrm{O} 3$ & 2.03 & 0.77 & 4.70 & 0.88 & 0.55 & 2.21 & 1.70 & 1.98 & 10.62 & 7.19 & 7.20 & 7.66 \\
$\mathrm{Fe} 2 \mathrm{O} 3$ & 13.07 & 18.25 & 15.27 & 19.38 & 18.32 & 16.78 & 15.64 & 12.70 & 10.06 & 14.50 & 14.19 & 13.89 \\
$\mathrm{MnO}$ & 0.15 & 0.15 & 0.22 & 0.20 & 0.15 & 0.25 & 0.25 & 0.22 & 0.18 & 0.23 & 0.25 & 0.21 \\
$\mathrm{MgO}$ & 30.26 & 29.52 & 23.11 & 28.65 & 32.45 & 25.12 & 24.52 & 21.79 & 14.35 & 17.20 & 18.71 & 18.59 \\
$\mathrm{CaO}$ & 2.77 & 1.92 & 8.57 & 2.30 & 0.50 & 4.05 & 2.50 & 7.64 & 12.88 & 9.12 & 7.06 & 8.22 \\
$\mathrm{Na} 2 \mathrm{O}$ & 0.19 & 0.04 & 0.30 & 0.07 & 0.01 & 0.11 & 0.05 & 0.30 & 0.75 & 0.88 & 0.52 & 0.41 \\
$\mathrm{~K} 2 \mathrm{O}$ & 0.04 & 0.04 & 0.04 & 0.04 & 0.04 & 0.04 & 0.04 & 0.04 & 0.04 & 0.06 & 0.04 & 0.04 \\
$\mathrm{P} 2 \mathrm{O} 5$ & 0.01 & 0.02 & 0.01 & 0.02 & 0.01 & 0.02 & 0.02 & 0.02 & 0.01 & 0.03 & 0.01 & 0.07 \\
$\mathrm{LOI}$ & 13.70 & 11.80 & 5.10 & 9.80 & 11.10 & 0.10 & 3.50 & 2.20 & 0.90 & 0.20 & 0.20 & 0.10 \\
$\mathrm{Total}$ & 99.25 & 99.29 & 99.79 & 99.28 & 99.31 & 99.57 & 99.43 & 99.63 & 99.75 & 99.83 & 99.84 & 99.80 \\
$\mathrm{Mg} \#$ & 82.10 & 76.21 & 74.98 & 74.54 & 77.82 & 74.78 & 75.64 & 77.26 & 73.86 & 70.14 & 72.31 & 72.61 \\
\hline
\end{tabular}


Table 3. Cont.

\begin{tabular}{|c|ccccc|}
\hline \multicolumn{5}{|c|}{ Melagabbronorite } \\
\hline Sample & 140 & 142 & 143 & 144 & 145 \\
\hline $\mathrm{SiO} 2$ & 52.47 & 54.29 & 54.43 & 52.31 & 48.03 \\
$\mathrm{TiO} 2$ & 0.67 & 0.71 & 0.39 & 0.23 & 0.55 \\
$\mathrm{~A} 2 \mathrm{O} 3$ & 16.91 & 17.01 & 17.37 & 19.98 & 18.22 \\
$\mathrm{Fe} 2 \mathrm{O} 3$ & 9.10 & 8.97 & 8.25 & 6.89 & 9.16 \\
$\mathrm{MnO}$ & 0.14 & 0.14 & 0.13 & 0.10 & 0.15 \\
$\mathrm{MgO}$ & 7.97 & 5.70 & 6.60 & 7.82 & 8.55 \\
$\mathrm{CaO}$ & 9.72 & 9.17 & 8.97 & 8.91 & 12.68 \\
$\mathrm{Na} 2 \mathrm{O}$ & 2.90 & 3.29 & 3.41 & 3.06 & 1.52 \\
$\mathrm{~K} 2 \mathrm{O}$ & 0.17 & 0.27 & 0.23 & 0.13 & 0.07 \\
$\mathrm{P} 2 \mathrm{O} 5$ & 0.04 & 0.11 & 0.08 & 0.02 & 0.02 \\
$\mathrm{LOI}$ & 0.10 & 0.30 & 0.10 & 0.50 & 1.00 \\
$\mathrm{Total}$ & 100.43 & 99.96 & 99.96 & 99.95 & 99.95 \\
$\mathrm{Mg} \#$ & 63.43 & 55.72 & 61.31 & 69.21 & 64.89 \\
\hline
\end{tabular}

On the AFM diagram, the ophiolitic ultramafic and cumulate gabbronorite plot along the $\mathrm{MgO}-\mathrm{FeO}$ side in the tholeiitic field while those of the melagabbronorite plot close to boundary between the calc-alkaline and tholeiitic fields (Fig. 10A). The southern ultramafic-mafic rocks are plotted on Jensen diagram (Jensen, 1976) to determine their parent liquid composition as well as the genetic relationship of these rocks. The southern ultramafic rocks are plotted entirely in the ultramafic komatiite field (Fig. 11), while those of the cumulate gabbronorite plot entirely in the basaltic komatiite field. The melagabbronorite samples plot collectively within the calc-alkaline field. This confirms the presence of three distinct magmatic units revealed from the major element variation.

Moreover, the plot does not follow Skaergaard trend, indicating a more mafic liquid source for the southern ultramafic-mafic rocks when compared with those from the Khamal anorthosite-gabbro complex on the AFM diagram (Fig. 10B \&14) indicating that the former is probably derived from a source rather different from magma source(s) which formed the Khamal anorthosite-gabbro complex. 

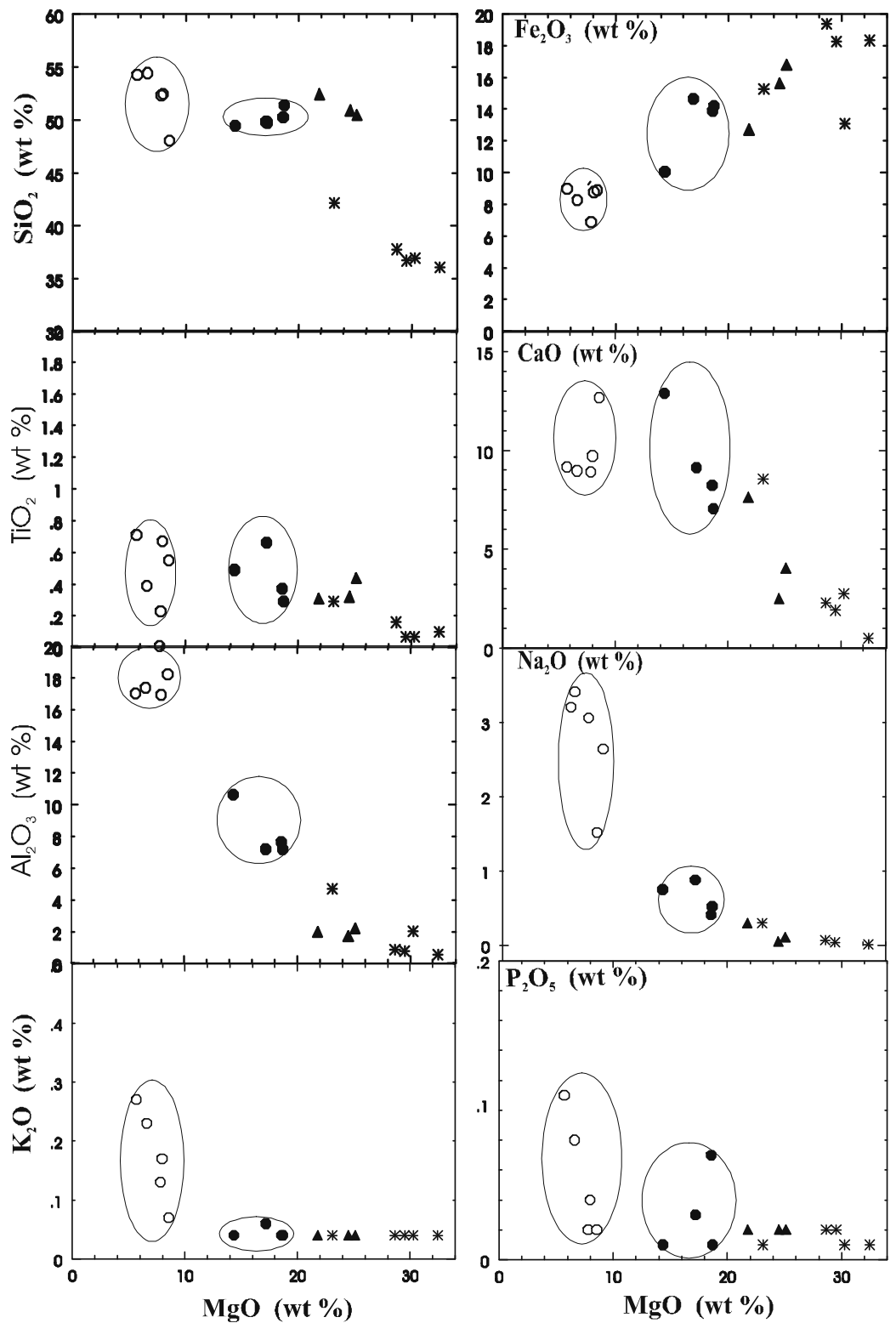

Fig. 8. Variation of major elements (wt \%) verus $\mathrm{MgO}$ (wt \%) for the southern ultramaficmafic rocks.

O Melagabbronorite

$\Delta$ Pyroxenite

- Cumulate gabbronorite $*$ Ultramafic rocks (Peridotite) 


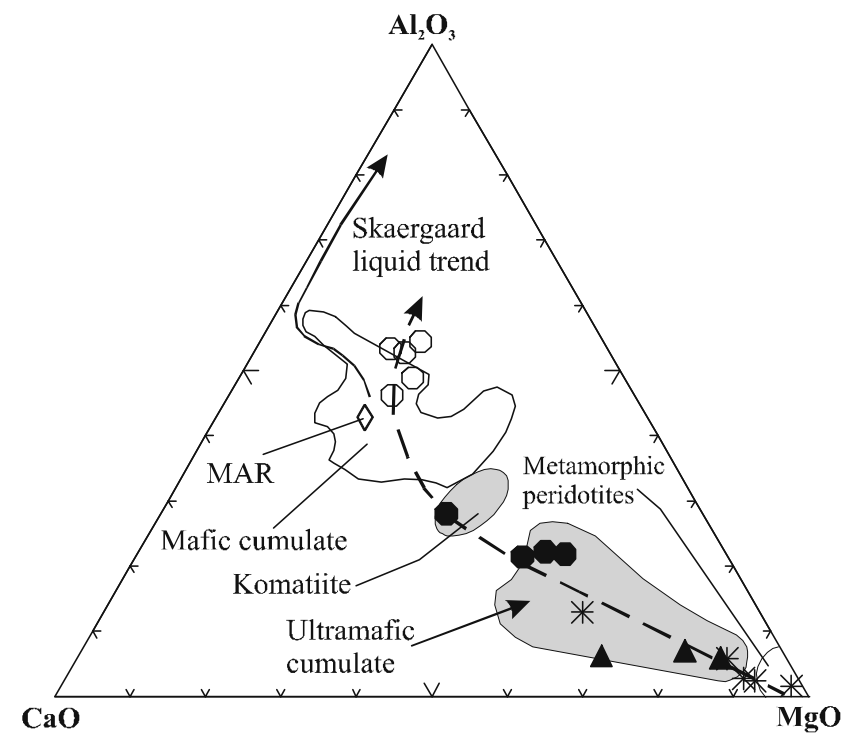

Fig. 9. Ternary diagram of $\mathrm{MgO}-\mathrm{CaO}-\mathrm{Al}_{2} \mathrm{O}_{3}$ (after Coleman, 1977) for the southern ultramafic-mafic rocks. MAR represents the average composition of the mid-ocean ridge basalts. Skaergaard liquid trend is plotted for comparison with the southern ultramafic-mafic rocks trend (dashed arrow).

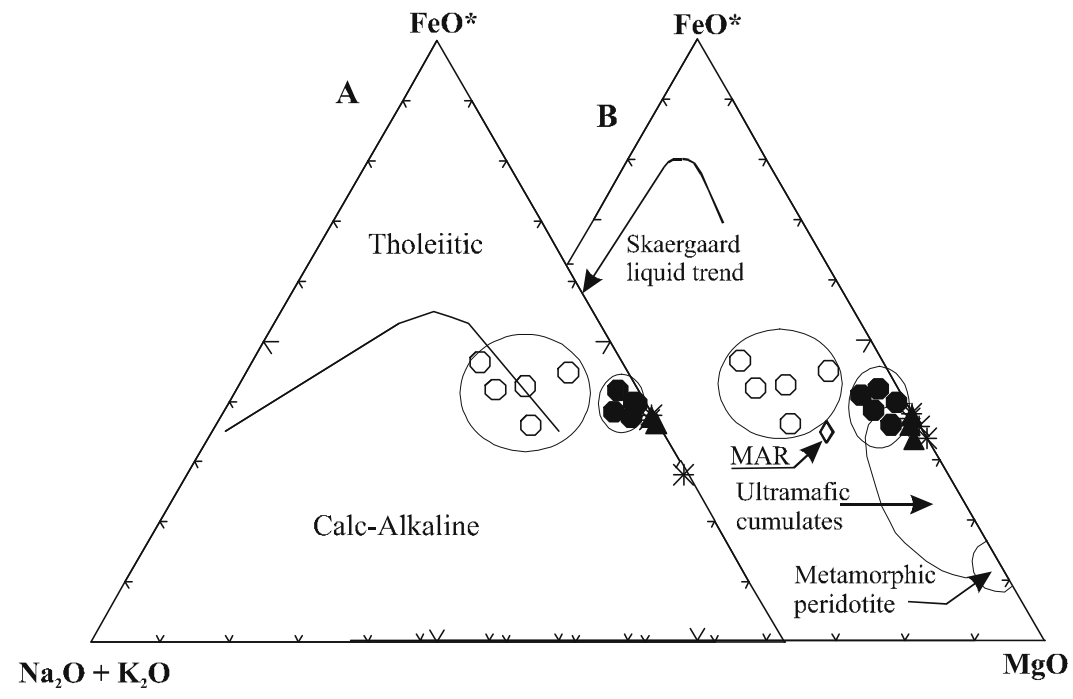

Fig. 10. AFM diagram of the southern ultramafic-mafic rocks. The field boundary between tholeiitic and calc-alkaline fields in (A) is after Irvine and Baragar (1971). MAR is the average composition of mid-oceanic ridge basalt. Other fields in (B) are after Coleman (1977). 


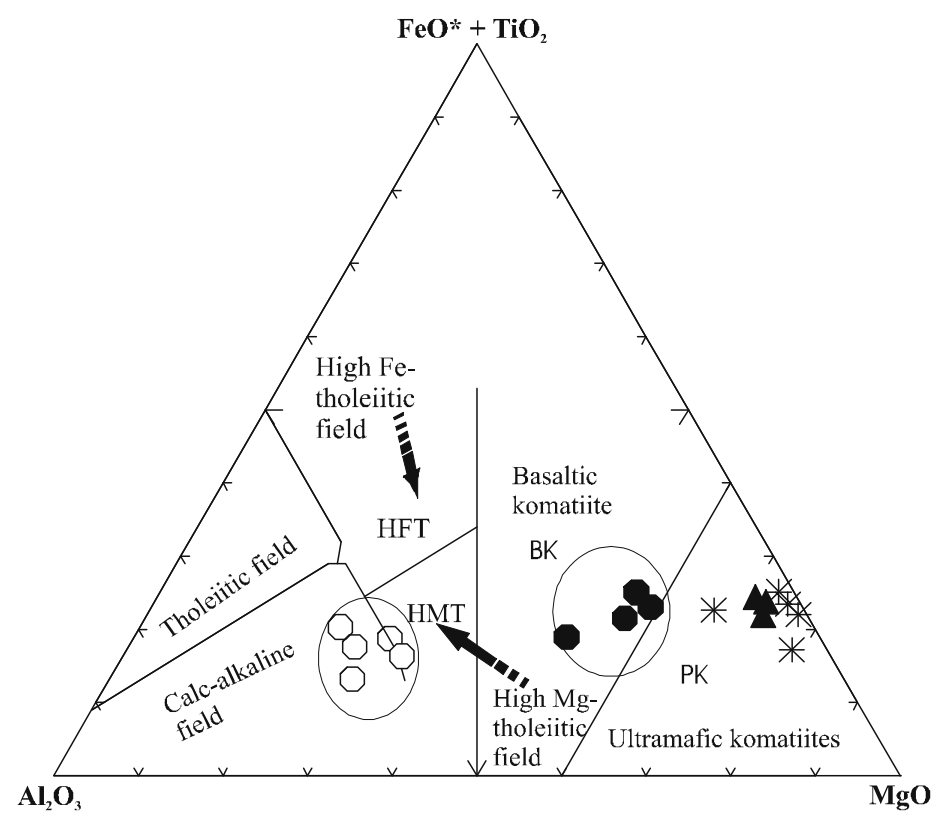

Fig. 11. Jensen cationic plot of $\mathrm{Al}_{2} \mathrm{O}_{3},(\mathrm{FeO} *+\mathrm{TiO2})$ and $\mathrm{MgO}$ (after Jensen, 1976) for the southern ultramafic-mafic rocks.

\section{Major Elements Characteristics of the Wadi Khamal Complex}

The major element concentrations of samples from the different rock types of the whole KAGC generally reflect the wide change in the modal composition from the marginal gabbro unit (KU1) to the northern one (KU4). The major element variations are wide and conspicuous among the gabbroic rocks of the KAGC (Table 4). The variation diagrams using the $\mathrm{Mg}$-number $(\mathrm{Mg} \#)$ as index of differentiation $(\mathrm{Mg} \#=\mathrm{Mg} / \mathrm{Mg}+\mathrm{Fe} \mathrm{x}$ 100) (Fig. 12A to I) show that the marginal, central and northern gabbros have three distinct and different trends. $\mathrm{SiO}_{2}, \mathrm{Al}_{2} \mathrm{O}_{3}, \mathrm{CaO}, \mathrm{MgO}$ and $\mathrm{Na}_{2} \mathrm{O}$ decrease with increasing differentiation (decrease $\mathrm{Mg} \#$ ), $\mathrm{Fe}_{2} \mathrm{O}_{3}$ increases with increasing differentiation. The anorthosite samples display wide variation in the $\mathrm{Mg}$-number $(\mathrm{Mg} \#=30-65)$, with limited variations in $\mathrm{SiO}_{2}, \mathrm{TiO}_{2}, \mathrm{CaO}$ and $\mathrm{MgO}$ which indicate variable modal content of the ferromagnesian minerals. The change in the complex, grading inwards from medium-grained gabbro to anorthositic gabbro to gabbroic anorthosite, and then to the anorthosite is consistent with the chemical variations portrayed on most of the diagrams (Fig. 12). This indicates the cogenetic and co-magmatic relationship of the anorthosite and the rocks of the outer marginal gabbro unit. 

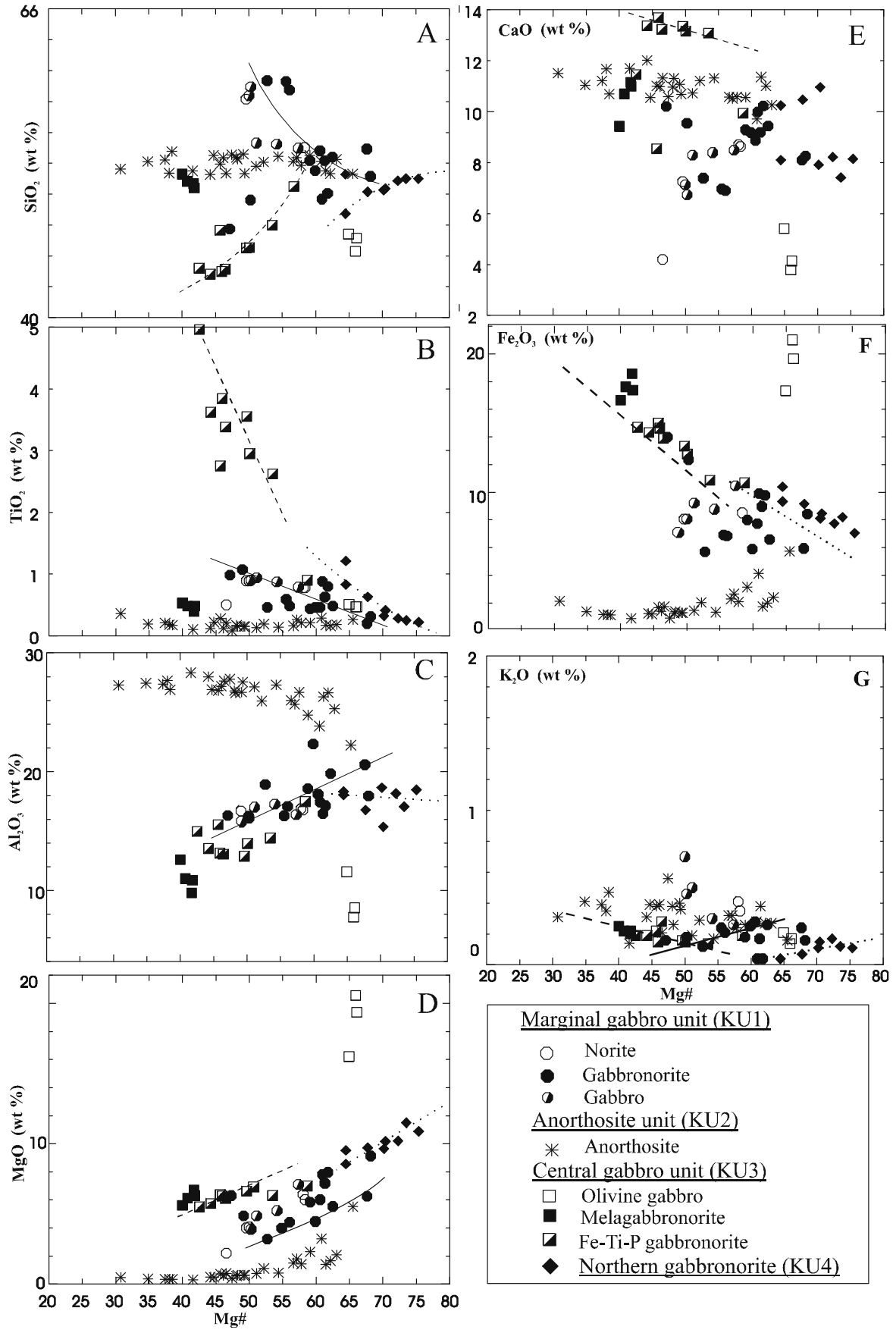

Marginal gabbro unit (KU1)

- Norite

- Gabbronorite

- Gabbro

Anorthosite unit (KU2)

* Anorthosite

Central gabbro unit (KU3)

$\square \quad$ Olivine gabbro

- Melagabbronorite

( Fe-Ti-P gabbronorite

- Northern gabbronorite (KU4)

Fig. 12. Variation of major elements versus magnesium number (Mg\#) of the rocks of the Khamal anorthosite-gabbro complex. The solid, dashed and dotted lines are the inferred fractionation trends of the units KU1, KU3 and KU4, respectively. 

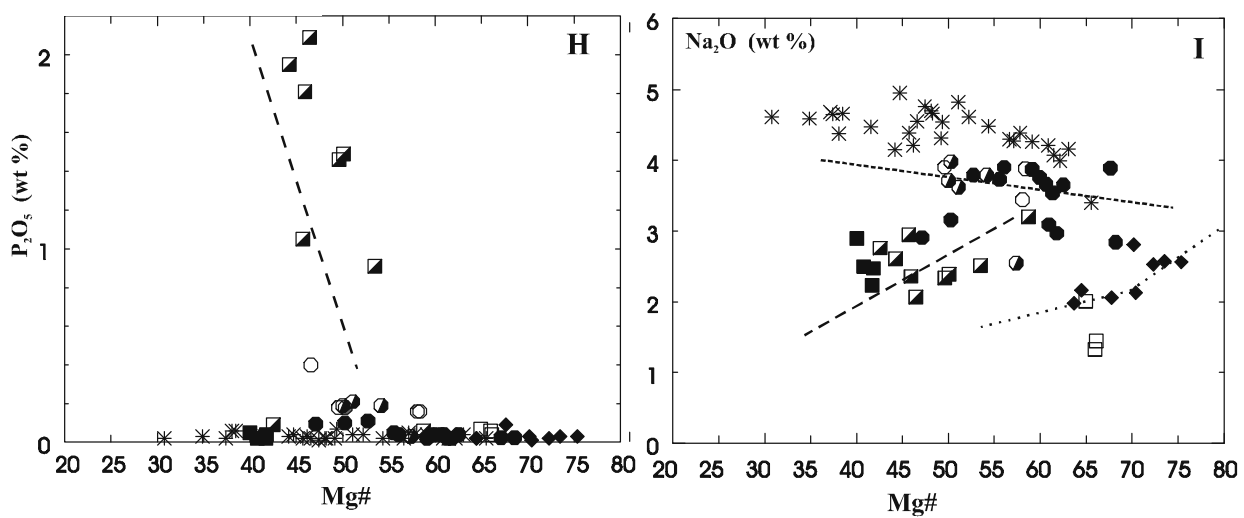

Fig. 12. Contd.

The marginal gabbro samples display more scatter, variable and wide major oxides variations especially $\mathrm{SiO}_{2}$ (47.46-59.96\%), $\mathrm{Al}_{2} \mathrm{O}_{3}$ (11.4$22.33 \%), \mathrm{CaO}$ (6.73-10.22\%) and $\mathrm{Mg} \#$ (47.11-69.63\%) which may reflect some sort of contamination particularly in samples collected close to the contact with host country rocks, where, they contain the highest $\mathrm{SiO}_{2}$ $\left(\mathrm{SiO}_{2}>57 \%\right)$. The central gabbro unit (KU3) comprises the olivine gabbro, melagabbronorite and $\mathrm{Fe}-\mathrm{Ti}$ oxides-apatite gabbronorite (ilmenitemagnetite-apatite gabbronorite). These three rock types show distinct trends and cluster on the variation diagrams. They have characteristic enrichment and depletion in their major elements. Compared to the gabbroic rocks from both the marginal (KU1) and the northern gabbros (KU4), the rocks of the central gabbroic unit (KU3) with the exception of olivine gabbro, are markedly enriched in $\mathrm{TiO}_{2}(0.39-4.96 \%), \mathrm{Fe}_{2} \mathrm{O}_{3}$ (9.73-21.03\%), $\mathrm{P}_{2} \mathrm{O}_{5}(0.04-2.09 \%), \mathrm{CaO}(8.55-13.70 \%)$; and still lower in $\mathrm{Na}_{2} \mathrm{O}, \mathrm{K}_{2} \mathrm{O}$ and $\mathrm{Al}_{2} \mathrm{O}_{3}$. This may indicate that the central gabbroic rocks were derived from a different magma source and/or have different evolution and fractionation trend. The olivine gabbro of the central gabbro unit (KU3) forms a separate array with highest $\mathrm{MgO}$ and extremely low $\mathrm{K}_{2} \mathrm{O}, \mathrm{Na}_{2} \mathrm{O}$ and $\mathrm{CaO}$ on the variation diagrams. These rocks most probably resulted from accumulation of olivine, orthopyroxene $\pm \mathrm{Fe}-\mathrm{Ti}$ oxides during crystallization, and therefore do not represent any liquid composition (Areback, 1995).

The northern gabbronorite unit (KU4) is represented by the gabbronorite samples which are less evolved and have the highest $\mathrm{Mg}$ number $(\mathrm{Mg} \#=56.4-75.36)$. They display a different fractionation trend on the variation diagrams (Fig. 12), where $\mathrm{SiO}_{2}, \mathrm{Al}_{2} \mathrm{O}_{3}, \mathrm{MgO}, \mathrm{Na}_{2} \mathrm{O}$ decrease with decreasing $\mathrm{Mg} \#$ while $\mathrm{TiO}_{2}, \mathrm{Fe}_{2} \mathrm{O}_{3}$, and $\mathrm{CaO}$ increase. 
Table 4. Major oxides of rocks from the wadi Khamal anorthosite-gabbro complex.

\begin{tabular}{|c|c|c|c|c|c|c|c|c|c|c|c|}
\hline \multirow[b]{3}{*}{ Sample } & \multicolumn{11}{|c|}{ Marginal Gabbro unit KU1 } \\
\hline & \multicolumn{3}{|c|}{ Coarse-grained Norite } & \multicolumn{8}{|c|}{ Medium grained gabbronorite } \\
\hline & 10 & 19 & 25 & 1 & 3 & 6 & 7 & 8 & 9 & 17 & 20 \\
\hline $\mathrm{SiO} 2$ & 58.40 & 53.47 & 54.34 & 50.46 & 49.99 & 59.88 & 59.18 & 54.06 & 54.21 & 49.90 & 59.96 \\
\hline $\mathrm{TiO} 2$ & 0.89 & 0.78 & 0.78 & 0.80 & 0.88 & 0.59 & 0.48 & 0.46 & 0.44 & 0.83 & 0.46 \\
\hline $\mathrm{Al} 2 \mathrm{O} 3$ & 16.41 & 16.90 & 16.77 & 17.13 & 17.44 & 16.30 & 17.08 & 18.10 & 20.60 & 16.28 & 18.92 \\
\hline $\mathrm{Fe} 2 \mathrm{O} 3$ & 8.08 & 9.14 & 8.51 & 9.77 & 9.91 & 6.91 & 6.86 & 7.74 & 5.94 & 12.37 & 5.70 \\
\hline $\mathrm{MnO}$ & 0.12 & 0.14 & 0.12 & 0.15 & 0.15 & 0.11 & 0.10 & 0.12 & 0.09 & 0.17 & 0.10 \\
\hline $\mathrm{MgO}$ & 4.01 & 6.39 & 6.02 & 7.97 & 7.81 & 4.36 & 4.42 & 6.02 & 6.27 & 6.31 & 3.21 \\
\hline $\mathrm{CaO}$ & 7.26 & 8.70 & 8.64 & 10.22 & 9.99 & 6.96 & 6.90 & 8.86 & 8.10 & 9.55 & 7.39 \\
\hline $\mathrm{Na} 2 \mathrm{O}$ & 3.90 & 3.44 & 3.88 & 2.97 & 3.09 & 3.73 & 3.90 & 3.66 & 3.89 & 3.16 & 3.79 \\
\hline $\mathrm{K} 2 \mathrm{O}$ & 0.44 & 0.41 & 0.35 & 0.04 & 0.04 & 0.24 & 0.21 & 0.28 & 0.24 & 0.18 & 0.12 \\
\hline $\mathrm{P} 2 \mathrm{O} 5$ & 0.18 & 0.16 & 0.16 & 0.02 & 0.04 & 0.05 & 0.04 & 0.04 & 0.02 & 0.10 & 0.11 \\
\hline LOI & 0.10 & 0.40 & 0.20 & 0.40 & 0.60 & 0.70 & 0.80 & 0.60 & 0.40 & 0.10 & 0.20 \\
\hline Total & 99.79 & 99.93 & 99.77 & 99.93 & 99.94 & 99.83 & 99.97 & 99.94 & 100.2 & 98.95 & 99.96 \\
\hline $\mathrm{Mg \#}$ & 49.57 & 58.06 & 58.35 & 61.77 & 60.95 & 55.55 & 56.06 & 60.63 & 67.64 & 50.25 & 52.73 \\
\hline & \multicolumn{6}{|c|}{ Medium grained gabbronorite (KU1) } & \multicolumn{5}{|c|}{ Gabbro (KU1) } \\
\hline Sample & 21 & 18 & 23 & 24 & 46 & 64 & 4 & 5 & 12 & 13 & 26 \\
\hline $\mathrm{SiO} 2$ & 51.90 & 47.46 & 53.22 & 53.22 & 52.39 & 53.53 & 59.45 & 54.28 & 58.69 & 54.70 & 54.61 \\
\hline $\mathrm{TiO} 2$ & 0.31 & 0.98 & 0.44 & 0.63 & 0.46 & 0.58 & 0.90 & 0.79 & 0.89 & 0.94 & 0.87 \\
\hline $\mathrm{Al} 2 \mathrm{O} 3$ & 17.96 & 16.31 & 18.58 & 16.46 & 22.33 & 19.85 & 16.11 & 16.40 & 16.30 & 17.02 & 17.28 \\
\hline $\mathrm{Fe} 2 \mathrm{O} 3$ & 8.44 & 14.01 & 8.00 & 8.98 & 5.91 & 6.58 & 7.66 & 10.46 & 8.06 & 9.21 & 8.78 \\
\hline $\mathrm{MnO}$ & 0.13 & 0.16 & 0.13 & 0.14 & 0.08 & 0.13 & 0.11 & 0.17 & 0.12 & 0.13 & 0.13 \\
\hline $\mathrm{MgO}$ & 9.14 & 6.30 & 5.84 & 7.19 & 4.46 & 5.54 & 3.91 & 7.11 & 4.07 & 4.86 & 5.24 \\
\hline $\mathrm{CaO}$ & 8.26 & 10.20 & 9.29 & 9.19 & 9.18 & 9.44 & 6.73 & 8.49 & 7.13 & 8.29 & 8.39 \\
\hline $\mathrm{Na} 2 \mathrm{O}$ & 2.84 & 2.91 & 3.87 & 3.54 & 3.76 & 3.65 & 3.98 & 2.55 & 3.71 & 3.62 & 3.79 \\
\hline $\mathrm{K} 2 \mathrm{O}$ & 0.16 & 0.16 & 0.18 & 0.17 & 0.25 & 0.26 & 0.46 & 0.26 & 0.70 & 0.50 & 0.30 \\
\hline $\mathrm{P} 2 \mathrm{O} 5$ & 0.02 & 0.04 & 0.02 & 0.02 & 0.04 & 0.04 & 0.18 & 0.03 & 0.19 & 0.21 & 0.19 \\
\hline LOI & 0.80 & 0.50 & 0.40 & 0.40 & 1.10 & 0.70 & 0.30 & 0.60 & 0.10 & 0.30 & 0.20 \\
\hline Total & 99.96 & 99.03 & 99.97 & 99.94 & 99.96 & 100.3 & 99.79 & 101.1 & 99.96 & 99.78 & 99.78 \\
\hline $\mathrm{Mg \#}$ & 68.20 & 47.11 & 59.11 & 61.33 & 59.91 & 62.51 & 50.27 & 69.63 & 50.00 & 51.10 & 54.17 \\
\hline \multicolumn{12}{|c|}{ Anorthosite unit KU2 } \\
\hline Sample & 2 & 27 & 28 & 29 & 30 & 31 & 32 & 33 & 34 & 35 & 36 \\
\hline $\mathrm{SiO} 2$ & 53.14 & 53.29 & 52.16 & 53.15 & 52.52 & 52.82 & 53.66 & 53.10 & 53.51 & 53.47 & 52.94 \\
\hline $\mathrm{TiO} 2$ & 0.16 & 0.21 & 0.18 & 0.19 & 0.36 & 0.21 & 0.21 & 0.19 & 0.17 & 0.26 & 0.28 \\
\hline $\mathrm{Al} 2 \mathrm{O} 3$ & 26.02 & 27.38 & 27.67 & 27.46 & 27.29 & 26.69 & 24.77 & 25.95 & 26.82 & 25.69 & 26.83 \\
\hline $\mathrm{Fe} 2 \mathrm{O} 3$ & 2.29 & 1.16 & 1.16 & 1.37 & 2.14 & 2.08 & 3.15 & 2.03 & 1.26 & 2.66 & 1.67 \\
\hline $\mathrm{MnO}$ & 0.02 & 0.01 & 0.02 & 0.01 & 0.02 & 0.03 & 0.04 & 0.02 & 0.02 & 0.03 & 0.03 \\
\hline $\mathrm{MgO}$ & 1.51 & 0.35 & 0.36 & 0.37 & 0.48 & 1.44 & 2.30 & 1.12 & 0.59 & 1.79 & 0.71 \\
\hline $\mathrm{CaO}$ & 10.58 & 11.21 & 11.68 & 11.04 & 11.51 & 10.59 & 10.56 & 11.21 & 10.97 & 10.52 & 11.01 \\
\hline $\mathrm{Na} 2 \mathrm{O}$ & 4.30 & 4.65 & 4.38 & 4.59 & 4.61 & 4.39 & 4.26 & 4.61 & 4.70 & 4.27 & 4.39 \\
\hline $\mathrm{K} 2 \mathrm{O}$ & 0.32 & 0.39 & 0.35 & 0.41 & 0.31 & 0.24 & 0.26 & 0.29 & 0.38 & 0.32 & 0.38 \\
\hline $\mathrm{P} 2 \mathrm{O} 5$ & 0.02 & 0.02 & 0.06 & 0.03 & 0.02 & 0.04 & 0.04 & 0.04 & 0.02 & 0.05 & 0.02 \\
\hline LOI & 1.60 & 1.30 & 1.80 & 1.20 & 0.50 & 1.40 & 0.70 & 1.40 & 1.50 & 0.90 & 1.70 \\
\hline Total & 99.96 & 99.97 & 99.82 & 99.82 & 99.76 & 99.93 & 99.95 & 99.96 & 99.94 & 99.96 & 99.96 \\
\hline $\mathrm{Mg \#}$ & 56.63 & 37.40 & 38.07 & 34.85 & 30.76 & 57.82 & 59.12 & 52.21 & 48.11 & 57.13 & 45.71 \\
\hline
\end{tabular}


Table 4. Contd.

\begin{tabular}{|c|c|c|c|c|c|c|c|c|c|c|c|}
\hline \multicolumn{12}{|c|}{ Anorthosite unit KU2 } \\
\hline Sample & 37 & 38 & 39 & 40 & 41 & 42 & 44 & 45 & 47 & 49 & 50 \\
\hline $\mathrm{SiO} 2$ & 52.15 & 52.06 & 53.76 & 53.37 & 53.47 & 52.13 & 53.57 & 54.00 & 52.37 & 53.72 & 53.34 \\
\hline $\mathrm{TiO} 2$ & 0.21 & 0.12 & 0.15 & 0.15 & 0.12 & 0.16 & 0.14 & 0.17 & 0.17 & 0.08 & 0.18 \\
\hline $\mathrm{Al} 2 \mathrm{O} 3$ & 27.66 & 28.01 & 26.70 & 26.65 & 27.20 & 26.66 & 27.32 & 26.91 & 26.32 & 27.81 & 25.29 \\
\hline $\mathrm{Fe} 2 \mathrm{O} 3$ & 1.75 & 1.25 & 1.29 & 1.38 & 1.41 & 2.00 & 1.33 & 1.14 & 1.75 & 0.90 & 2.41 \\
\hline $\mathrm{MnO}$ & 0.02 & 0.02 & 0.01 & 0.01 & 0.02 & 0.03 & 0.01 & 0.01 & 0.03 & 0.01 & 0.03 \\
\hline $\mathrm{MgO}$ & 0.77 & 0.50 & 0.63 & 0.65 & 0.61 & 1.66 & 0.80 & 0.36 & 1.41 & 0.41 & 2.08 \\
\hline $\mathrm{CaO}$ & 11.33 & 12.02 & 11.08 & 11.31 & 10.98 & 11.01 & 11.32 & 10.69 & 11.36 & 10.59 & 10.26 \\
\hline $\mathrm{Na} 2 \mathrm{O}$ & 4.55 & 4.15 & 4.31 & 4.66 & 4.21 & 3.99 & 4.48 & 4.66 & 4.07 & 4.76 & 4.16 \\
\hline $\mathrm{K} 2 \mathrm{O}$ & 0.21 & 0.31 & 0.40 & 0.26 & 0.39 & 0.27 & 0.17 & 0.47 & 0.38 & 0.56 & 0.27 \\
\hline $\mathrm{P} 2 \mathrm{O} 5$ & 0.02 & 0.03 & 0.02 & 0.02 & 0.03 & 0.02 & 0.02 & 0.06 & 0.02 & 0.01 & 0.04 \\
\hline LOI & 1.30 & 1.50 & 1.60 & 1.50 & 1.50 & 2.00 & 0.80 & 1.50 & 2.10 & 1.10 & 1.90 \\
\hline Total & 99.97 & 99.97 & 99.95 & 99.96 & 99.94 & 99.93 & 99.96 & 99.97 & 99.98 & 99.95 & 99.96 \\
\hline $\mathrm{Mg} \#$ & 46.56 & 44.20 & 49.17 & 48.26 & 46.14 & 62.17 & 54.36 & 38.48 & 61.47 & 47.43 & 63.09 \\
\hline \multicolumn{7}{|c|}{ Anorthosite } & \multicolumn{3}{|c|}{ Olvine gabbro } & \multicolumn{2}{|c|}{$\begin{array}{c}\text { Mela- } \\
\text { gabbronorite }\end{array}$} \\
\hline Sample & 51 & 52 & 53 & 54 & 55 & 57 & 14 & 15 & 16 & 72 & 73 \\
\hline $\mathrm{SiO} 2$ & 53.17 & 52.76 & 52.15 & 52.37 & 53.68 & 52.11 & 45.60 & 46.70 & 47.04 & 51.03 & 52.09 \\
\hline $\mathrm{TiO} 2$ & 0.29 & 0.13 & 0.15 & 0.10 & 0.22 & 0.26 & 0.47 & 0.47 & 0.51 & 0.90 & 0.53 \\
\hline $\mathrm{Al} 2 \mathrm{O} 3$ & 23.85 & 27.15 & 27.55 & 28.33 & 26.93 & 22.24 & 7.77 & 8.54 & 11.57 & 17.48 & 12.60 \\
\hline $\mathrm{Fe} 2 \mathrm{O} 3$ & 4.13 & 1.46 & 1.30 & 0.89 & 1.20 & 5.75 & 21.03 & 19.66 & 17.35 & 9.73 & 16.67 \\
\hline $\mathrm{MnO}$ & 0.06 & 0.02 & 0.02 & 0.01 & 0.02 & 0.08 & 0.27 & 0.27 & 0.23 & 0.15 & 0.40 \\
\hline $\mathrm{MgO}$ & 3.24 & 0.77 & 0.64 & 0.32 & 0.49 & 5.52 & 20.58 & 19.37 & 16.22 & 6.99 & 5.61 \\
\hline $\mathrm{CaO}$ & 9.71 & 10.73 & 10.68 & 11.70 & 10.55 & 9.60 & 3.79 & 4.14 & 5.41 & 9.94 & 9.43 \\
\hline $\mathrm{Na} 2 \mathrm{O}$ & 4.21 & 4.82 & 4.54 & 4.47 & 4.95 & 3.40 & 1.33 & 1.45 & 2.01 & 3.20 & 2.89 \\
\hline $\mathrm{K} 2 \mathrm{O}$ & 0.28 & 0.19 & 0.36 & 0.14 & 0.39 & 0.16 & 0.14 & 0.17 & 0.21 & 0.19 & 0.25 \\
\hline $\mathrm{P} 2 \mathrm{O} 5$ & 0.02 & 0.04 & 0.07 & 0.03 & 0.04 & 0.02 & 0.06 & 0.04 & 0.07 & 0.06 & 0.05 \\
\hline LOI & 1.00 & 1.90 & 2.50 & 1.60 & 1.50 & 0.70 & 0.10 & 0.10 & 0.10 & 0.30 & 0.10 \\
\hline Total & 99.96 & 99.97 & 99.96 & 99.96 & 99.97 & 99.84 & 101.1 & 100.9 & 100.7 & 99.97 & 100.6 \\
\hline \multirow[t]{2}{*}{ Mg\# } & 60.84 & 51.09 & 49.37 & 41.59 & 44.71 & 65.53 & 65.96 & 66.12 & 64.93 & 58.72 & 39.99 \\
\hline & \multicolumn{3}{|c|}{ Melagabbronorite } & & \multicolumn{7}{|c|}{ Fe-Ti oxides-apatite gabbronorite } \\
\hline Sample & 74 & 75 & 76 & 65 & 66 & 67 & 68 & 69 & 70 & 71 & 77 \\
\hline $\mathrm{SiO} 2$ & 50.92 & 51.49 & 51.30 & 47.77 & 45.91 & 43.89 & 47.35 & 44.07 & 43.66 & 45.87 & 44.16 \\
\hline $\mathrm{TiO} 2$ & 0.48 & 0.48 & 0.39 & 2.62 & 2.95 & 3.84 & 2.75 & 3.38 & 3.62 & 3.55 & 4.96 \\
\hline $\mathrm{Al} 2 \mathrm{O} 3$ & 10.86 & 11.00 & 9.79 & 14.42 & 13.95 & 13.15 & 15.54 & 13.05 & 13.54 & 12.88 & 14.97 \\
\hline $\mathrm{Fe} 2 \mathrm{O} 3$ & 17.39 & 17.63 & 18.57 & 10.87 & 12.77 & 14.64 & 15.03 & 13.90 & 14.32 & 13.33 & 14.70 \\
\hline $\mathrm{MnO}$ & 0.44 & 0.44 & 0.47 & 0.17 & 0.18 & 0.17 & 0.23 & 0.20 & 0.16 & 0.18 & 0.15 \\
\hline $\mathrm{MgO}$ & 6.31 & 6.13 & 6.71 & 6.32 & 6.47 & 6.28 & 6.38 & 6.09 & 5.74 & 6.63 & 5.50 \\
\hline $\mathrm{CaO}$ & 10.99 & 10.70 & 11.15 & 13.09 & 13.16 & 13.70 & 8.55 & 13.23 & 13.37 & 13.36 & 11.46 \\
\hline $\mathrm{Na} 2 \mathrm{O}$ & 2.47 & 2.50 & 2.23 & 2.51 & 2.39 & 2.36 & 2.95 & 2.07 & 2.61 & 2.34 & 2.76 \\
\hline $\mathrm{K} 2 \mathrm{O}$ & 0.22 & 0.22 & 0.20 & 0.14 & 0.15 & 0.15 & 0.22 & 0.28 & 0.19 & 0.16 & 0.19 \\
\hline $\mathrm{P} 2 \mathrm{O} 5$ & 0.04 & 0.02 & 0.02 & 0.91 & 1.49 & 1.81 & 1.05 & 2.09 & 1.95 & 1.46 & 0.09 \\
\hline LOI & 0.10 & 0.10 & 0.10 & 1.00 & 0.40 & 0.10 & 0.10 & 1.60 & 0.80 & 0.20 & 0.10 \\
\hline Total & 100.2 & 100.7 & 100.9 & 99.82 & 99.82 & 100.1 & 100.1 & 99.96 & 99.96 & 99.96 & 99.04 \\
\hline $\mathrm{Mg} \#$ & 41.81 & 40.78 & 41.71 & 53.52 & 50.08 & 45.93 & 29.46 & 46.46 & 44.25 & 49.62 & 42.56 \\
\hline
\end{tabular}


Table 4. Contd.

\begin{tabular}{|c|cccccccc|}
\hline \multicolumn{10}{|c|}{ Northern gabbronorite unit KU4 } \\
\hline Sample & 22 & 43 & 58 & 59 & 60 & 61 & 62 & 63 \\
\hline $\mathrm{SiO} 2$ & 48.76 & 50.89 & 51.70 & 51.71 & 51.53 & 50.74 & 52.08 & 50.61 \\
$\mathrm{TiO} 2$ & 1.21 & 0.41 & 0.22 & 0.25 & 0.28 & 0.32 & 0.53 & 0.43 \\
$\mathrm{Al2O} 3$ & 18.04 & 15.36 & 18.49 & 17.06 & 18.18 & 18.66 & 18.34 & 16.78 \\
$\mathrm{Fe} 2 \mathrm{O} 3$ & 10.40 & 8.47 & 7.05 & 8.21 & 7.74 & 8.12 & 9.34 & 9.16 \\
$\mathrm{MnO}$ & 0.18 & 0.14 & 0.12 & 0.14 & 0.12 & 0.13 & 0.13 & 0.14 \\
$\mathrm{MgO}$ & 9.53 & 10.18 & 10.89 & 11.51 & 10.20 & 9.65 & 8.56 & 9.72 \\
$\mathrm{CaO}$ & 12.24 & 10.96 & 8.15 & 7.42 & 8.22 & 7.91 & 8.10 & 10.47 \\
$\mathrm{Na} 2 \mathrm{O}$ & 2.16 & 2.13 & 2.56 & 2.57 & 2.53 & 2.80 & 2.13 & 2.06 \\
$\mathrm{~K} 2 \mathrm{O}$ & 0.04 & 0.15 & 0.11 & 0.12 & 0.17 & 0.11 & 0.04 & 0.07 \\
$\mathrm{P} 2 \mathrm{O} 5$ & 0.02 & 0.01 & 0.03 & 0.03 & 0.02 & 0.03 & 0.02 & 0.03 \\
$\mathrm{LOI}$ & 0.40 & 1.20 & 0.60 & 0.90 & 0.90 & 0.10 & 0.40 & 0.10 \\
$\mathrm{Total}$ & 102.98 & 99.90 & 99.92 & 99.92 & 99.89 & 98.57 & 99.67 & 99.57 \\
$\mathrm{Mg} \#$ & 62.34 & 70.42 & 75.36 & 73.52 & 72.30 & 56.40 & 58.18 & 67.76 \\
\hline
\end{tabular}

$\mathrm{Mg} \#=(\mathrm{Mg} / \mathrm{Mg}+\mathrm{FeO}) \times 100$.

The anorthosite samples from the Khamal anorthosite-gabbro complex tend to be higher in feldspar components $\left(\mathrm{Al}_{2} \mathrm{O}_{3}, \mathrm{CaO}, \mathrm{Na}_{2} \mathrm{O}\right.$ and $\mathrm{K}_{2} \mathrm{O}$ ) (Fig. 12, Table 4) compared with the more mafic member of the complex.

Comparing with other worldwide massif-type anorthosite suites, the field relationships and geochemical trends are most easily explained by crystal melt fractionation and accumulation of plagioclase feldspar (e.g. Buddington, 1972; Haskin and Salpas, 1992; Ashwal, 1993; Markl and Frost, 1999). For example, $\mathrm{Fe}_{2} \mathrm{O}_{3}{ }^{*}$ and $\mathrm{MgO}$ decrease and $\mathrm{Al}_{2} \mathrm{O}_{3}$ and $\mathrm{CaO}$ increase from marginal gabbroic rocks (norite, gabbronorite and gabbro) to anorthosite (Fig. 13A \& B). This trend reflects the gradational change in modal proportions of primary cumulates plagioclase and pyroxene (e.g. Simmons and Hanson, 1978). The trends of the Khamal anorthositegabbro complex (Fig. 13A and B) are very similar and coincide with the evolution trends of the Red River anorthosite suite (Miller and Barr, 2000).

The AFM diagrams (Fig. 14A \& B) show significant variation among the four units of the Khamal anorthosite-gabbro complex. It is evident that both the marginal gabbro unit (KU1) and anorthosite unit (KU2) have a calc alkaline differentiation trend while those of the central gabbro unit (KU3) and the northern gabbronorite (KU4) show a distinct and different trend parallel to the $\mathrm{FeO}^{*}-\mathrm{MgO}$ side line and belong to the tholeiitic differentiation (Fig. 14B). 
According to the classification of Le Maitre (1989), both calc alkaline and tholeiitic rocks belong to the low-K series. On the classification $\mathrm{K}_{2} \mathrm{O}-\mathrm{SiO}_{2}$ diagram, all the investigated rocks of the Khamal anorthositegabbro complex plot in the low K-field (Fig. 15). However, the presence of both calc-alkaline and tholeiitic rocks in the same complex was described in Laouri area, Algeria (Cottin et al., 1998).
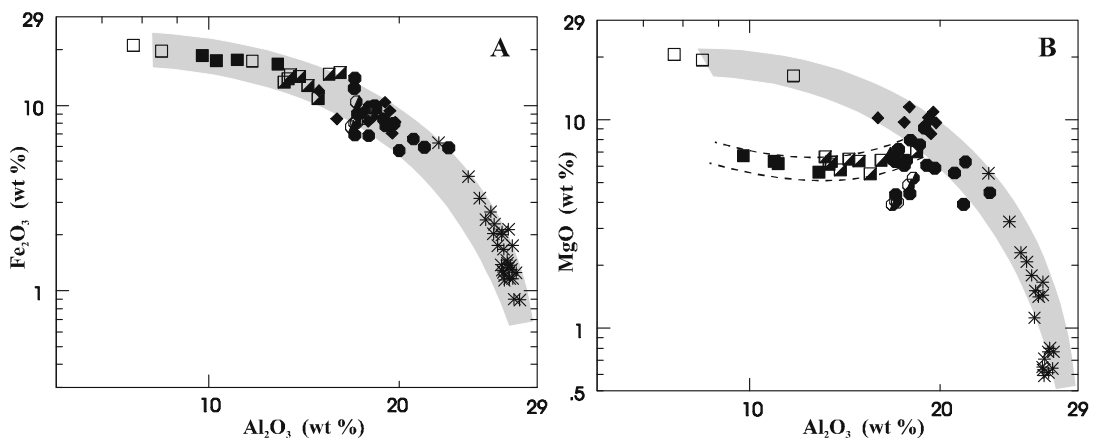

Fig. 13. Plots of (A) $\mathrm{FeO}^{*}$ against $\mathrm{Al}_{2} \mathrm{O}_{3}$, and (B) $\mathrm{MgO}$ against $\mathrm{Al}_{2} \mathrm{O}_{3}$ illustrating the differing evolutionary trends for samples from the Khamal anorthosite-gabbro complex. Symbols as in Fig. 12. The stippled field is the evolutionary trend of the Red River anorthosite suite and Charnockite unit (Miller and Barr, 2000).

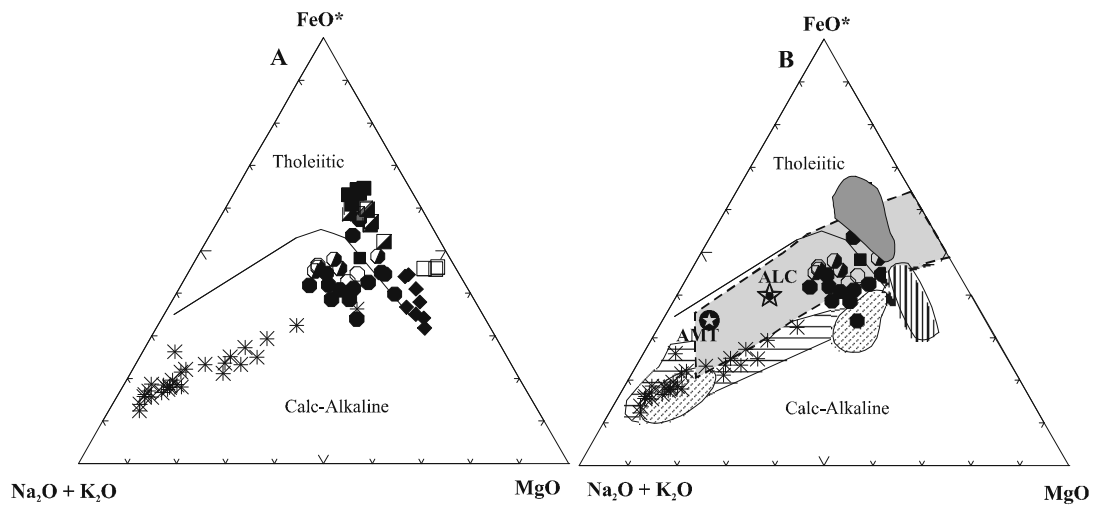

Fig. 14. AFM diagram (A) for the different rocks in the Khamal anorthosite-gabbro complex and (B) the chemographic trends of Khamal anorthosite-gabbro complex compared with anorthosite from other localities. AMT (star in black circle) is an average for massif-type anorthosite, ALC (Star with black dot) for layered igneous complexes, both calculated from average values for individual complexes given by Ashwal (1993). Light stippled field is field of Laramie Anorthosite complex (Mitchell et al., 1995). Diagonally lined fields represent the Qasad anorthosite, AJibub area, Arabian Shield (French and Sindi, 1983). Horizontal lined field is the Khamal anorthosite, KU2; Vertically lined field is the northern gabbro unite (KU4); heavy stippled field is the central gabbro unit (KU3). 


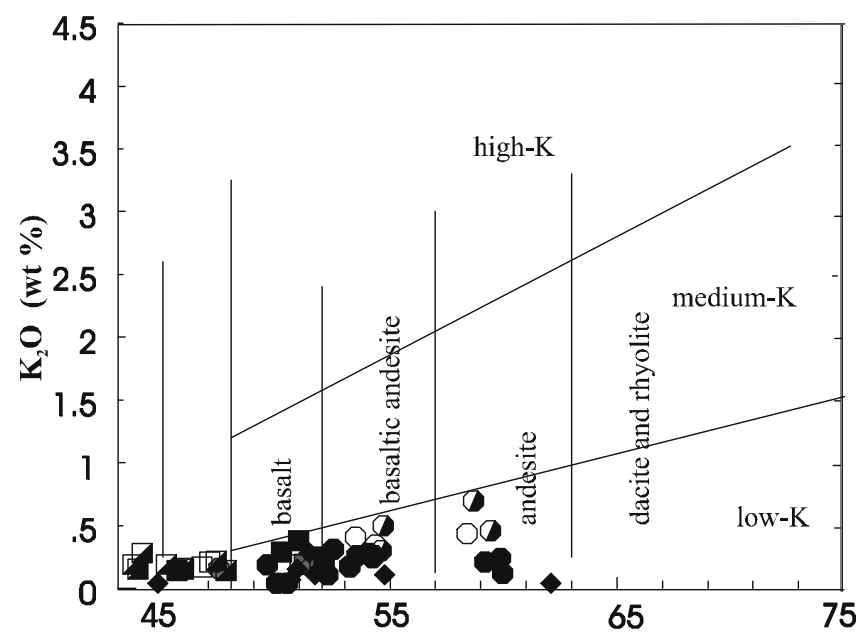

Fig. 15. $\mathrm{K}_{2} \mathrm{O}$ versus $\mathrm{SiO}_{2}$ discrimination diagram for the Khamal anorthosite gabbro complex. The high-, medium- and low-K fields are from Gill (1981). Other symbols as in Fig. 12.

\section{Summary and Conclusions}

Field, petrography and major elements geochemistry of the ultramafic -mafic rocks of Wadi Khamal area led to the recognition of the following rock groups, namely: 1) ophiolitic suite, melagabbronorite and cumulate gabbronorite to the south of Wadi Mahalah (southern ultramafic-mafic rocks) and 2) Wadi Khamal anorthosite-gabbro complex to the north.

The geochemical investigation is adopted first to verify the petrologic subdivision of both the KAGC and the southern ultramafic-mafic rocks and clarify the geochemical characteristics of the rocks of each rock unit. The second approach is the attempt to determine whether these rock units are genetically-related and derived from the same magma source or they are evolved from more than one source.

A general inspection of the compositional variation of the major elements in the different rocks confirms the existence of four magmatic units in KAGC (KU1, KU2, KU3 and KU4) distinct from the ophiolitic ultramafic (serpentinite, peridotites and pyroxenites) and mafic (melagabbronorite and cumulate gabbronorite) rocks exposed in the southern area. 
Unlike the Khamal complex, the southern ultramafic-mafic rocks are not genetically related. The serpentinites, peridotites, pyroxenites and cumulate gabbronorite show peculiar major elements composition and variation which indicate that they were derived from Mg-rich (komatiitic) basaltic source. However, field study has revealed that the cumulate gabbronorite intruded the ultramafic rocks in the southern area. The melagabbronorite is likely to be derived from calc alkaline magma.

The different rock types in the four units of the KAGC (KU1 to KU4) have major elements characteristics suggesting that these rocks were derived from three different magma sources.

The marginal gabbros and anorthosites units (KU1 and KU2, respectively) constitute a compositional continuum with a wide range in most of their major elements composition which indicate the co-magmatic relationship and suggest they were derived from the same source.

Khamal anorthosite shows an overall chemical abundance and distinct trend on most of the variation diagrams. They show marked depletion in major elements compositions which are indicative to their calcalkaline affinity. These chemical features are indicators of high degrees of plagioclase accumulation and common characteristics of massif-type anorthosite (Ashwal, 1993; Gerninger et al., 1998).

The central gabbronorite unit (KU3) is markedly enriched in $\mathrm{TiO}_{2}$ $(0.4-4.96 \mathrm{wt} \%), \mathrm{Fe}_{2} \mathrm{O}_{3}(9.7-21 \mathrm{wt} \%), \mathrm{P}_{2} \mathrm{O}_{5}(0.04-2.09 \mathrm{wt} \%)$ and $\mathrm{CaO}(8.55-13.7 \mathrm{wt} \%)$ suggesting an Fe-rich tholeiitic magma.

The rocks of the northern gabbronorite unit (KU4) have the highest $\mathrm{Mg}$ number $\left(\mathrm{Mg}^{*}=56-75\right.$ with an average value $\left.=67\right)$, and therefore are considered as the least evolved rocks within the Khamal anorthositegabbro complex.

Concerning the Fe-Ti oxide mineralizations, two main types were recognized and are associated with the Wadi Khamal central Fe-Ti oxides-apatite gabbronorite unit (KU3):

1) Massive nelsonite bands consisting of magnetite-ilmenite and apatite in different proportions with minor interstitial silicates.

2) Massive magnetite-ilmenite ore which is present either as bands intercalated with nelsonite or as dike-like bodies hosted by the anorthosite 
in contact with Fe-Ti oxides-apatite gabbronorite with nelsonite envelopes of variable thicknesses.

The Fe-Ti oxide \pm apatite deposits are known to be associated with Proterozoic massif anorthosites and related rocks (Kolker, 1982; Epler et al., 1986; Force and Carter, 1986; Areback and Stigh, 2000; Dymek, and Owens, 2001), and tholeiitic layered intrusions (Reynolds, 1985a and b; Von Gruenewaldt et al., 1985; Klemm et al., 1985; McCann et al., 1998; Ripley et al., 1998).

Different hypotheses have been proposed for the origin of oxidesapatite rocks associated with massif anorthosites and include; hydrothermal replacement of preexisting rocks (Ross, 1941); immiscibility of oxide-apatite melt with oxides: apatite ratio $\approx 2: 1$ (Philpotts, 1967); accumulation of apatite and oxide minerals by crystal settling (Emslie, 1975); fractional crystallization prior to melt immiscibility for Fe-Ti oxide deposits with widely variable apatite and silicates contents (McLelland et al., 1994); extreme crystal fractionation, unless partial melting of Ti and $\mathrm{P}$ rich crustal rocks has occurred (Naslund et al., 2002 and Nabil et al., 2003); products of cumulus development and subsequent mobilization through filter pressing for ore with variable apatite content (Dymek and Owens, 2001).

Reynolds (1985a) divided the ores associated with the upper zone of Bushveld Complex into three groups; 1) apatite poor high Ti-magnetite association, 2) apatite poor low Ti-magnetite association, and 3) apatite rich high Ti magnetite association. Apatite poor high Ti-magnetite and apatite-poor low Ti-magnetite associations are present both as disseminations and ore-rich layers. These associations were formed in response to normal fractional crystallization processes, the formation of ore-rich layers being triggered by episodic increase in $f_{2}$. The formation of apatite rich-high Ti magnetite association which is present both as disseminations and ore-rich layers is attributed to the separation of immiscible FeTi-P enriched liquids from late stage dioritic residual melt.

Bergstol (1972) described an association of magnetite, ilmenite and apatite ore in the form of a dike, referred to as jacupirangite, cutting through larvikite and nordmarkite. The jacupirangite shows oxides: apatite ratio of 2:1 and attributed its formation to an immiscible oxide-apatite melt during the fractionation of a monzonitic magma and the melt accumulated at the lower part of the magma chamber as magmatic segrega- 
tions. Under favorable tectonic conditions, the segregated melt was injected into the surrounding rocks.

Previous studies by Chevremont and Johan (1981) identified two types of Fe-Ti oxide mineralization. The first type is located at the base of the anorthosite unit, originating from an iron-rich residual liquid expelled downwards as a result of plagioclase flotation. The second type occurs as lenses of disseminated to massive magnetite-ilmenite in a melagabbro intrusion (oxides-apatite gabbronorite of the present study) close to the anorthosite. This implies that the anorthosites and the Fe-Ti oxides-apatite gabbronorite were crystallized from one and the same magma.

Any model proposed for Wadi Khamal Fe-Ti oxide and apatite mineralization should explain the following field, petrographic and geochemical features:

1- The close spatial association of the massive ores with Fe-Ti oxides -apatite gabbronorite. The contact between the massive ore and the Fe-Ti oxides-apatite gabbronorite host is gradational. Also the contact between the nelsonite and the massive magnetite-ilmenite ore bands is gradational.

2- The similarity of the ore minerals in types 1 and 2 and in the Fe-Ti oxides-apatite gabbronorite.

3- The nelsonites do not have a 2:1 oxides/apatite ratios where the apatite contents range between $15-40 \%$ with an average of about $25 \%$.

4- Type 2 is devoid of apatite and is composed essentially of magnetite and ilmenite and its presence as dike-like bodies with nelsonite selvages in anorthosites adjacent to the Fe-Ti oxide-apatite gabbronorite.

5- The occurrence of large anorthosite blocks within the melagabbronorite (which is enriched both in sulfides and Fe-Ti oxides associated with the cumulus pyroxene bands) and the Fe-Ti oxides-apatite gabbronorite.

6- The presence of apatite as cumulus crystals with early formed pyroxenes and plagioclases.

7- Late crystallization of the Fe-Ti oxides interstitial to silicates.

8- The presence of ovoid inclusions from gabbronorite in the massive nelsonite ore. 
9- The geochemical studies indicate that the marginal gabbro unit (KU1) and the anorthosites (KU2) were crystallized from the same magma and was intruded later by a tholeiitic magma which upon fractional crystallization gave the different rocks of the central gabbroic unit (olivine gabbro, melagabbronorite and $\mathrm{Fe}-\mathrm{Ti}$ oxides-apatite gabbronorite with the associated Fe-Ti oxides and apatite ores).

The above mentioned features lead to the suggestion of the following stages for the origin of the Wadi Khamal Fe-Ti oxides \pm apatite mineralizations;

1- The anorthosite was intruded by a magma which upon fractionation gave rise to an early differentiates (olivine gabbro and melagabbronorite) and a residual liquid enriched in Fe-Ti-P.

2- Apatite was separated as a cumulus phase with plagioclases and pyroxenes.

3- With progressive fractional crystallization, the interstitial melt was more enriched in Fe, $\mathrm{Ti}$ and $\mathrm{P}$ from which Fe-Ti oxides and apatite were crystallized and segregated by gravitational settling, thus leading to the formation of the massive ores. The mineralogical differences observed among the different types of the ores can be explained in terms of crystallization at different $f \mathrm{O}_{2}$ and temperatures.

4- Due to tectonic deformation, the segregated melt was injected via filter pressing into the surrounding anorthosite.

\section{Acknowledgment}

The author would like to thank Prof. A.A. Eldougdoug and Prof. M.A. Hassanen for their valuable discussions and comments during field work. Thanks to Prof. A. Al-Shanti for critically reviewing the manuscript. Thanks to the Deanship of Scientific Research (King Abdulaziz University,Jeddah) for funding the project on the Wadi Khamal area.

\section{References}

Al Ghamdi, A.M.Z. (1994) Mineralization and Associated Platinum Group Elements in mafic / ultramafic rocks, Northwestern Arabian Shield, K.S.A: Unpublished Ph.D. Thesis, King Abdulaziz University, Faculty of Earth Sciences.

Areback, H. (1995) The Hakefjorden Complex-Geology and Petrogenesis of a Late Sveconorwegian Norite-Anorthosite Intrusion, South-west Sweden, Ph.Lic. Thesis, Earth Sciences Centre, Goteborg University, A9, Goteborg, 84p. 
Areback, H. and Stigh, J. (2000) The Nature and Origin of an Nnorthosite Associated Ilmeniterich Leuconorite, Hakefjorden Complex, South-west Sweden: Lithos, 51: 247-267.

Ashwal, L.D. (1993) Anorthosites. Minerals and Rocks, 21, Springer- Verlag, Berlin, 422p.

Bache, J.J. and Chevermont, P. (1976) Mineral Investigations for Nickel and Copper in the Wadi Khamal Region: Bureau de Recherches Geologiques et Minieres, Open-File-ReportJED-OR-79:(8), 37p.

Bergstol, S. (1972) The Jacupirangite at Kodal, Vest fold, Norway. A Potential Magnetite, Ilmenite and Apatite Ore: Mineral. Deposita, 7: 233-246.

Buddington, A.F. (1972) Differentiation trends and parental magmas for anorthositic and quartz mangerite series, Adirondacks, New York. Geol. Soc. Am. Mem. 132: 477-488.

Chavez, P.S. and Bowell, J. (1988) Comparison of the Spectral Information Content of Landsat Thematic Mapper and SPOT for Three Different Sites in the Phoenix, Arizona Region: Photogrammetric Engineering \& Remote Sensing, 54 (12): 1699-1708.

Chevremont, P. and Johan, Z. (1981) Wadi Khamal-Wadi Murattijah Ultramafic-Mafic Layered Complex, Saudi Arabian Deputy Ministry for Mineral Resources: Open File Report BRGMOF-01(36), 143p.

Claesson, S., Pallister, J.S. and Tatsumoto, M. (1984) Sm-Nd Data on two Late Proterozoic Ophiolites of Saudi Arabia and Implications for Crustal and Mantle Evolution, Ministry of Petroleum and Mineral Resources, Deputy Ministry for Mineral Resources, Jeddah, Kingdom of Saudi Arabia: Open-File-Report USGS-OF-04(17), 27p.

Collenette, P. and Grainger, D.J. (1994) Mineral Resources of Saudi Arabia, DGMR Special publication SP-2, Ministry of Petroleum and Mineral Resources, Directorate General of Mineral Resources, Jeddah, Kingdom of Saudi Arabia.

Coleman, R. G. (1977) Ophiolites-ancient Oceanic Lithosphere, Berlin, Springer- Verlag, New York.

Cottin, J.Y., Lorand, J.P., Agrinier, P., Bodinier, J.L. and Liegeois, J.P. (1998) Isotopic (O, Sr, Nd) and Trace Element Geochemistry of the Laouni Layered Intrusions (Pan-African belt, Hoggar, Algeria): Evidence for Post-Collisional Continental Tholeiitic Magmas Variably Contaminated by Continental Crust. Lithos, 45: 197-222.

Drury, S. (1993) Image Interpretation in Geology ( ${ }^{\text {nd }}$ edition, Chapman and Hall, London).

Dymek, R.F. and Owens, B.E. (2001) Petrogenessis of Apatite-rich Rocks (Nelsonites and oxide-Apatite Gabbronorites) Associated with Massif Anorthosites: Econ. Geol., 96: 797-815.

Emslie, R.F. (1975) Major Rock Units of the Main Complex, Southwestern Quebec, Canada: Geol. Survey Paper 74:(84), 37p.

Emslie, R.F. and Hegner, E. (1993) Reconnaissance Isotopic Geochemistry of AnorthositeMangerite-Charnockite-Granite (AMCG) Complex: Isotope and Chemical Evidence from the Nain Plutonic Suite: J. Geol., 102, 539-558.

Epler, N.E., Bolsover, L.R. and Lindsley, D.H. (1986) Nature and Origin of the Sbille Fe-Ti Oxide Deposit, Laramie Anorthosite Complex: SE Wyoming (abs), Geological Society of America Abstracts with programs, 18: 595.

Force, E.R. and Carter, B.A. (1986) Liquid Immiscibility Proposed for Nelsonitic Components of the Anorthosite-Syenite-Gabbro Complex, San Gabriel Mountains, California: (abs.), Geological Society of America, Abstracts with Programs, 18: 604.

French, W. J. and Sindi, H. O. (1983) The Qasad Anorthosite, Al Jibub Kingdom of Saudi Arabia. King Abdulaziz University, Bull. Fac. Sci., 6: 233-248.

Gerninger, G.J., Schoch, A.E., Sukhanov, M. and Zhuravlev, D. (1998) Geochemcial and Isotopic Characteristics of Different Types of Anorthosites in the Namaqua, Mobile Belt, South Africa, Chem. Geol., 145: 17-46.

Gill, J.B. (1981) Orogenic Andesite and Plate Tectonics. New York: Springer-Verlag, 390.

Harbi, H.M., Eldougdoug A.A., Hassanen, M.A. and Al Filali, I.Y. (2006) Economic Potentiality and Petrogenetic Evolution of the Mafic-Ultramafic Rocks in the Wadi Khamal Area, 
Northwestern Arabian Shield, Saudi Arabia. Funded by King Abdulaziz University, Institute of Research and Consultation.

Hashem, W.B. (1981) The Geology of the Wadi Khamal Basic Layered Intrusion, Yanbou Al Bahr, Saudi Arabia, Unpublished Ph.D Thesis, University of Bristol, UK., 503p.

Haskin, L.A. and Salpas, P.A. (1992) Genesis of Compositional Characteristics of Stillwater AN-1 and AN-II Thick Anorthosite Units. Geochimica. Cosmochimica Acta, 56: 1187-1212.

Irvine, T.N. and Baragar, R.A. (1971) A Guide to Chemical Classification of the Common Volcanic Rocks. Canad. J. Earth Sci., 8: 523-548.

Jensen, L.S. (1976) A New Cation Plot for Classifying Sub-lkaline Volcanic Rocks, Ontario Dept. Mines, Misc. paper 66.

Kemp, J., Pellaton, C. and Calvez, J.Y. (1980) Geochronological and Geological History in the Precambrian Northwestern Saudi Arabia, Saudi Arabian Deputy Ministry for Mineral Resources: Open-File-Report BRGM-OF-01:(1), 120p.

Klemm, D.D., Henckel, J. and Dehm, R.M., Von Gruenewaldt, G. (1985) The Geochemistry of Titanomagnetites from Massive Magnetite Layers and their Host rocks of the Upper Zone, Eastern Bushveld Complex: Econ. Geol., 80: 1075-1088.

Kolker, A. (1982) Mineralogy and Geochemistry of Fe-Ti Oxide and Apatite (Nelsonite) Deposits and Evolution of the Liquid Immiscibility Hypothesis: Econ. Geol., 77: 1146-1158.

Le Maitre, R.W. (1989) A Classification of Igneous Rocks and Glossary Terms, Blackwell Scientific Publications, Oxford. 193p.

Madani, A. (2003) Evaluation of the Fusion of Landsat Thematic Mapper Imagery and Scanned Aerial Photograph for Mapping the Trachytic Ring dykes, Wadi Natash Area, South Eastern Desert, Egypt, $5^{\text {th }}$ Int. Conf. on the Geol. Of the Middle East,2003, 509-517.

Markl, G. and Frost, B.R. (1999) The Origin of Anorthosite and Related Rocks from Lofoten Island, northern Norway. II Calculation of Parental Liquid Composition for Anorthosite, $J$. Petro., 40: 61-77.

McCann, A.J., Trzcienki, W.Jr. and Birkett, T.C. (1998) The Soquem Septa-Iles Fe-Ti-P Deposit (abs.), Geological Association of Canada: Mineralogical Association of Canada Program with Abstracts, 23: A121.

McLelland, J., Ashwal, Z. and Moore, L. (1994) Composition and Petrogenesis of Oxide-, Apatite Rich Gabbronorite Associated with Proterozoic Anorthosites Massifs: Examples from the Adirondack Mountains, New York: Contribution to Mineralogy and Petrology, 116: 225-238.

Miller, B.V. and Barr, S. M. (2000) Petrology and Isotopic Composition of a Grenvillian Basement Fragment in the Northern Appalachian Orogen: Blair River Inlier, Nova Scotia, Canada.

Mitchell, J.N., Scoates, J.S. and Frost, C.D. (1995) High-Al Gabbros in the Laramie Anorthosite Complex, Wyoming: Implications for the Compositions of Melts Parental to Proterozoic Anorthosite, Contrib. Mineral. Petrol., 119: 166-180.

Nabil, H., Barnes, S. and Higgins, M. (2003) Genesis of phosphorous and titanium deposits in the Septa Iles mafic intrusion (abs.). Canadian Institute of Mining, Metallurgy and Petroleum: Annual General Meeting, 105 ${ }^{\text {th }}$, Montreal Program, pp: 114-115.

Naslund, H.R., Henriquez, F., Nystrom, J.O., Vivallo, W. and Dobbs, F.M. (2002) Magmatic Iron Ores and Associated Mineralization: Examples from the Chilean High Andes and Coastal Cordillera, In: Porter, T.M., ed., Hydrothermal Iron Oxide-Copper-Gold and Related deposits: A global Perspective: Adelaide: South Australia, PGC Publishing, Porter Geoconsultancy Pty. Ltd., 2: 207-228.

Pellaton, C. (1979) Geologic Map of the Yanbu Al Bahr Quadrangle, Sheet 24C, Kingdom of Saudi Arabia, Saudi Dir. Gen. Miner. Resour. Geologic Map GM-48-A: 16p., 1pl.

Philpotts, A.R. (1967) Origin of Certain Iron-Titanium Oxide and Apatite Rocks: Econ. Geol., 62: 303-315. 
Reynolds, I.M. (1985a) Contrasted Mineralogy and Textural Relationships in the Upper Most Titaniferrous Magnetite Layers of the Bushveld Complex in the Bier Kraal Area, North of Rustenburg, Econ. Geol., 80: 1027-1048.

Reynolds, I.M. (1985b) The Nature and Origin of the Titaniferrous Magnetite Layers in the Upper Zone of the Bushveld Complex, Econ. Geol., 80: 1089-1108.

Ripley, E.M., Severson, M.J. and Hauck, S.A. (1998) Evidence for Sulfide and Fe-Ti-P Rich Liquid Immiscibility in the Duluth Complex, Minnesota, Econ. Geol., 93: 1052-1062.

Rose, A.W., Hawkes, H.E. and Webb, J.S. (1979) Geochemistry in Mineral Exploration, 2ed edition, academic press, $657 \mathrm{p}$.

Ross, C.S. (1941) Occurrence and Origin of Titanium Deposits of Nelson and Amherst Cunties, Virginia: U.S. Geol. Survey Prof. Paper 198, 58p.

Simmons, E.C. and Hanson, G.N. (1978) Geochemistry and Origin of Massif-Type Anorthosites. Contrib. Miner. Petro. 66: 119-135.

Von Gruenewaldt, G., Klemm, D.D., Henckel, J. and Dehm, R.M. (1985) Exsolution Features in Titanomagnetites from Massive Magnetite Layers and their Host Rocks of the Upper Zone, Eastern Bushveld Complex: Econ. Geol., 80: 1049-1061. 


\section{الجيولوجيا و الاستر اتجر افية الصخرية للصخور المافية - فوق المافية و التمعدنات المصاحبة لها، منطقة و ادي خمال، غرب وسط الدرع العربي}

\section{هشام محمد حربي}

قسم الثروة المعدنية والصخور - كلية علوم الأرض ملمب جامعة الملك عبدالعزبز - جدة - المدلكة العربية السعودية harbihesham@hotmail.com

الستتخلص. أدت الدراسات الحقلية، البتروجر افيــة وجيوكيميــاء

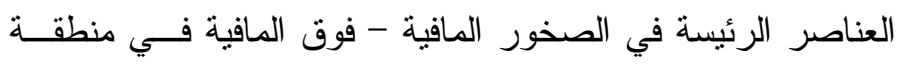

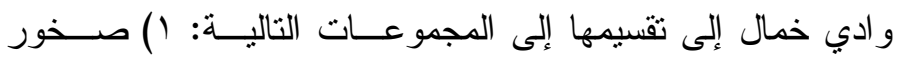

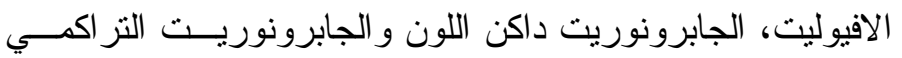

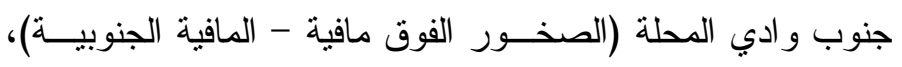
r معقد وادي خمال الأنورثويت - الجابرو في الثمال.

وتتضمن صخور الأفيوليت في المنطقة الجنوبية السربنتنيت،

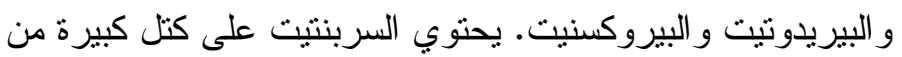

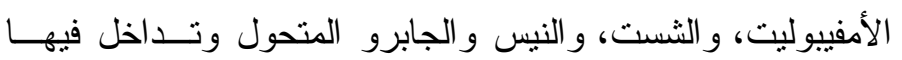
صخور الجابرو نوريت داكن اللون و الجابرو نوريت التزاكـــي. وهذه الصخور ثولييتية ما عدا الجابرو نوريت داكن اللون و الـــي نوني يقع في المجال الكلس قلوي. ويتكون معقد و ادي خهــال مــن أربــع وحــدات: الجــابرو

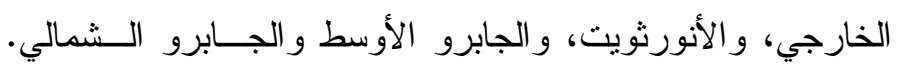

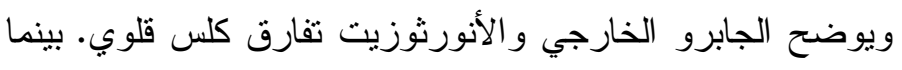


توضح صخور الجابرو الأوسط (الجابرو الأوليفينـي، وحديـــــ وتيتانيوم - وفوسفور جابرونوريت، وجابرونوريت داكن اللــون) و الجابرو الثمالي اتجاه تفارقي ثولييتي.

بناء على جيوكميائية العناصر الرئيسة فإن الصخور الفــوق

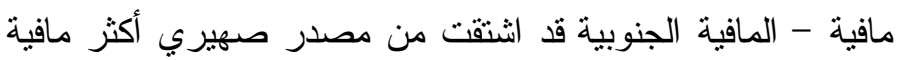
ومختلف عن مصدر (مصادر) الماجما التي كونت معقـــ خمــال

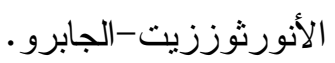

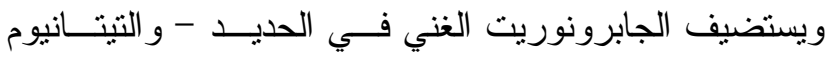

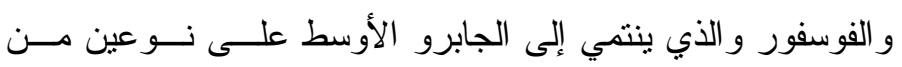

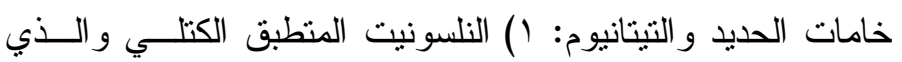

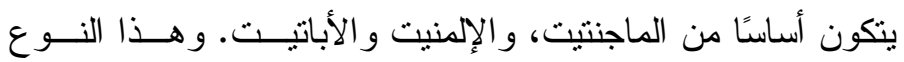

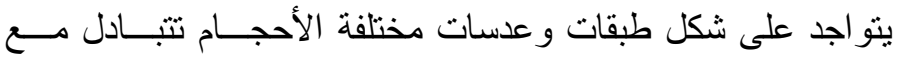
الجابرونوريت الغني في الحديد - و التيتانيوم و الفوسفور ، ؟) خــام

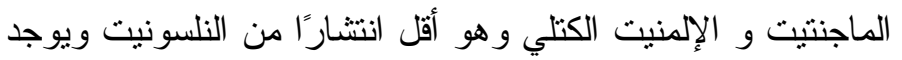

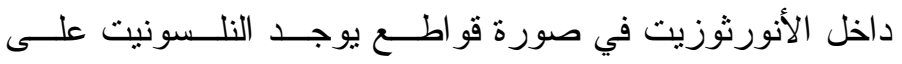

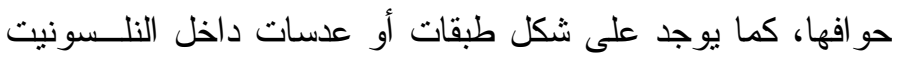

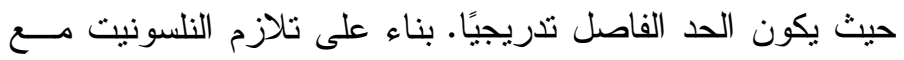

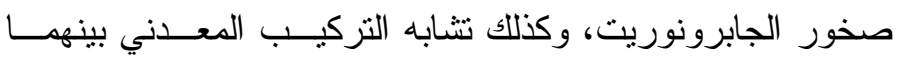

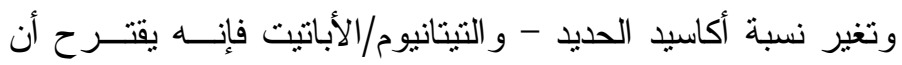
النلسونيت قد تكون كتجمعات بواسطة التبلور التجزيئسي المكــاني لماجما غنية في الحديد، و التيتانيوم، و الفوسفور و المكونات الطيارة،

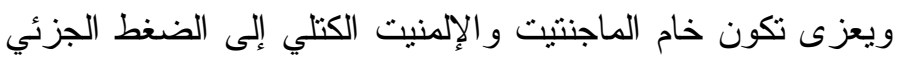

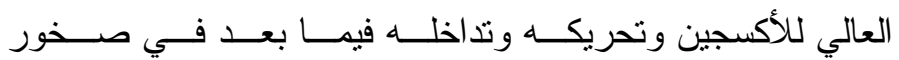
الأنورثوزيت المضيفة. 
